\title{
Comparative Analysis of METRIC Model and Atmometer Methods for Estimating Actual Evapotranspiration
}

\author{
Arturo Reyes-González, ${ }^{1}$ Jeppe Kjaersgaard, ${ }^{1,2}$ Todd Trooien, ${ }^{1}$ \\ Christopher Hay, ${ }^{3}$ and Laurent Ahiablame ${ }^{1}$ \\ ${ }^{1}$ Department of Agricultural and Biosystems Engineering, South Dakota State University, Brookings, SD 57007, USA \\ ${ }^{2}$ Minnesota Department of Agriculture, Saint Paul, MN, USA \\ ${ }^{3}$ Iowa Soybean Association, Ankeny, IA, USA \\ Correspondence should be addressed to Arturo Reyes-González; reyes.arturo@inifap.gob.mx
}

Received 28 April 2017; Revised 23 September 2017; Accepted 9 October 2017; Published 3 December 2017

Academic Editor: Othmane Merah

Copyright (C) 2017 Arturo Reyes-González et al. This is an open access article distributed under the Creative Commons Attribution License, which permits unrestricted use, distribution, and reproduction in any medium, provided the original work is properly cited.

\begin{abstract}
Accurate estimation of crop evapotranspiration (ET) is a key factor in agricultural water management including irrigated agriculture. The objective of this study was to compare ET estimated from the satellite-based remote sensing METRIC model to in situ atmometer readings. Atmometer readings were recorded from three sites in eastern South Dakota every morning between 8:15 and 8:30 AM for the duration of the 2016 growing season. Seven corresponding clear sky images from Landsat 7 and Landsat 8 (Path 29, Row 29) were processed and used for comparison. Three corn fields in three sites were used to compare actual evapotranspiration $\left(\mathrm{ET}_{\mathrm{a}}\right)$. The results showed a good relationship between $\mathrm{ET}_{\mathrm{a}}$ estimated by the METRIC model $\left(\mathrm{ET}_{\mathrm{a}}-\mathrm{METRIC}\right)$ and ET $\mathrm{a}$ estimated with atmometer $\left(\mathrm{ET}_{\mathrm{a}}\right.$-atm) $\left(r^{2}=0.87\right.$, index of agreement of 0.84 , and $\left.\mathrm{RMSE}=0.65 \mathrm{~mm} \mathrm{day}^{-1}\right)$. However, $\mathrm{ET}_{\mathrm{a}}$-atm values were consistently lower than $\mathrm{ET}_{\mathrm{a}}$-METRIC values. The differences in daily $\mathrm{ET}_{\mathrm{a}}$ between the two methods increase with high wind speed values $\left(>4 \mathrm{~m} \mathrm{~s}^{-1}\right)$. Results from this study are useful for improving irrigation water management at local and field scales.
\end{abstract}

\section{Introduction}

With increasing demands placed on freshwater resources worldwide, it is necessary to accurately estimate crop water consumption efficiently. Crop water use information is needed for a range of applications, including improving agricultural water management, irrigation and crop selection, water resource planning, water rights management, and water regulations [1-3]. Irrigated agriculture produces $40 \%$ of global food and fiber supply from $20 \%$ of the world's croplands [4]. In arid areas, up to $90 \%$ of all water withdrawals may be for irrigation purposes [5]. With increasing population and water uses a scarce water supply is put under additional pressure and other water users relying on the same water supply may experience insufficient water allocations. At the same time, a reduction of irrigation water supply may result in loss of production and, ultimately, threatened food security. There is an opportunity, however, to optimize the management of water in agricultural production systems, and the accurate estimation of evapotranspiration (ET) is critical in that regard.

ET is the loss of water from the land surface to the atmosphere through two processes, namely, evaporation (E) from soil and water surfaces and transpiration $(\mathrm{T})$ from vegetative surfaces $[6,7]$. ET rates are affected by weather conditions such as solar radiation, air temperature, wind speed and air vapor pressure deficit, and plant and soil characteristics conditions $[8,9]$. Different methods, direct and indirect, exist to estimate ET. Direct methods include weighing lysimeters and soil water balance estimations, while indirect methods include pan evaporation, atmometer, Bowen Ratio Energy Balance System (BREBS), Eddy Covariance (EC), scintillometer, sap flow, and remote sensing [1]. An attractive property of satellite-based remote sensing ET estimates using Landsat imagery is its coverage on a field by field basis at a regional scale $[1,10,11]$. 
Several models have been developed to estimate ET using remote sensing. One of them is the Mapping EvapoTranspiration at High Resolution using Internalized Calibration (METRIC) model. METRIC utilizes the innovative Surface Energy Balance Algorithm for Land (SEBAL) method for estimating sensible heat flux. METRIC uses the near surface to air temperature gradient $(d T)$ for each pixel within an image based on a regression relationship between the $d T$ and radiometric surface temperature $\left(T_{s}\right)$ of two anchor pixels. The anchor pixels represent the conditions of an agricultural field with full vegetation cover and maximum crop ET (cold condition) and a bare agricultural field with no vegetation cover (hot condition) $[10,12]$.

One of the advantages of the METRIC model compared to previous surface energy balance-based models for use in arid areas is that it utilizes reference evapotranspiration $\left(\mathrm{ET}_{\mathrm{r}}\right)$ for estimating actual evapotranspiration $\left(\mathrm{ET}_{\mathrm{a}}\right)$ at the cold pixel condition [10]. Because $\mathrm{ET}_{\mathrm{r}}$ is based on ground-based meteorological measurements and because $\mathrm{ET}_{\mathrm{r}}$ is calibrated to account for atmospheric conditions common in arid and semiarid conditions, such as horizontal advection, the METRIC model is particularly useful for $\mathrm{ET}_{\mathrm{a}}$ estimations under arid or semiarid conditions [10].

Previous studies have compared METRIC model outputs to other methods of $\mathrm{ET}_{\mathrm{a}}$ estimation such as weighing lysimeter [10], soil water balance [13], Bowen Ratio Energy Balance System (BREBS) [14-17], Eddy Covariance (EC), for example, [18-21], Large Aperture Scintillometer (LAS) [22], and the METRIC-MODIS method [23]. These studies showed from moderate to strong relationships between observed and METRIC-estimated $\mathrm{ET}_{\mathrm{a}}$, indicating that the METRIC model is a useful tool for estimating accurate $\mathrm{ET}_{\mathrm{a}}$ at local and field scales. In addition, the METRIC model has been compared with other models such as water balance model [24], trapezoid interpolation model (TIM) $[25,26]$, two-source energy balance model (TSEB) $[27,28]$, SIMDualKc model [29], and the Landsat-MODIS fusion model [30]. However, comparison of METRIC model outputs to an atmometer for $\mathrm{ET}_{\mathrm{a}}$ estimation has not yet been attempted.

An atmometer is a device that measures the amount of water evaporated from wet porous surface to the atmosphere [31]. Atmometers are simple and inexpensive devices, which consist of a ceramic evaporation plate (Bellani plate) covered by a green canvas, mounted on top of a cylindrical water reservoir, to provide a visual interpretation of atmospheric demand for pulling water out of the vegetation and the soil $[32,33]$. The standard model with number 54 green canvas is recommended for measuring alfalfa $\mathrm{ET}_{\mathrm{r}}$ similar to the alfalfabased Penman-Monteith $\mathrm{ET}_{\mathrm{r}}$, while number 30 green canvas is designed to simulate grass $\mathrm{ET}_{\mathrm{r}}$ similar to the grass-based Penman-Monteith ET $_{\mathrm{o}}[32,34]$.

Research demonstrated that $\mathrm{ET}_{\mathrm{r}}$ estimated with atmometers was moderately correlated $\left(r^{2}= \pm 0.70\right)$ with weighing lysimeters values $[35,36]$, strongly correlated $\left(r^{2}=0.90\right)$ with pan evaporation values $[37,38]$, and strongly correlated $\left(r^{2}=\right.$ 0.92 ) with agrometeorological data values, for example, [3943].
While METRIC is a well-recognized and widely used method to estimate ET, as noted by you, it is a complex and time intensive method that requires an experienced user to be run. For practical applications of crop water use estimations such as for irrigation scheduling, other in situ methods may be more appropriate. This is where atmometers may serve a purpose since they are simple and intuitive to use. They may be less accurate compared to other methods, but for applications where slightly higher uncertainty is acceptable, atmometers may be a good option. The objective of this study was to compare $\mathrm{ET}_{\mathrm{a}}$ estimated from satellite-based remote sensing METRIC model to $\mathrm{ET}_{\mathrm{a}}$ estimated with atmometers in corn fields in eastern South Dakota.

\section{Material and Methods}

2.1. Study Area. The study was carried out at three sites in eastern South Dakota at Brookings $\left(44^{\circ} 19^{\prime} \mathrm{N}, 96^{\circ} 46^{\prime} \mathrm{W}\right)$, Volga $\left(44^{\circ} 18^{\prime} \mathrm{N}, 96^{\circ} 55^{\prime} \mathrm{W}\right)$, and Oak Lake $\left(44^{\circ} 30^{\prime} \mathrm{N}, 96^{\circ} 31^{\prime} \mathrm{W}\right)$ at elevations 500, 497, and $574 \mathrm{~m}$ above sea level, respectively. Three corn fields near to each atmometer (within $5 \mathrm{~km}$ ) were selected and considered to estimate $\mathrm{ET}_{\mathrm{a}}$ (Figure 1). The population density was approximately 78,000 plants ha $^{-1}$ in all fields. Corn fields in Brookings and Volga had 0-2\% slope, while the Oak Lake had 2-6\% slope [44]. All fields used in this study are in corn-soybean crop rotation system. All corn fields emerged in early May and harvested in late October. The average annual precipitation is $533 \mathrm{~mm}$, of which 3/4 typically falls during the growing season April through October. The mean annual maximum temperature is $12.3^{\circ} \mathrm{C}$, minimum $0.3^{\circ} \mathrm{C}$, and mean $6.3^{\circ} \mathrm{C}$. The climate of the study area is classified as moist subhumid according to the Thornthwaite climate classification system [45].

2.2. Landsat Images. We used seven clear sky images from Landsat 7 Enhanced Thematic Mapper Plus (ETM+) and Landsat 8 Operational Land Imager (OLI) and Thermal Infrared Sensor (TIRS) (Path 29, Row 29), Table 1. The images were downloaded from the United States Geological Survey (USGS) EROS Datacenter (http://glovis.usgs.gov) [46]. The images were selected based on the temporal coverage and cloud-free conditions. Images with cloud located $>10 \mathrm{~km}$ from all study sites were considered acceptable. The images were processed using the METRIC model running in ERDAS Imagine Software environment [47]. The time of satellite overpass of both Landsats ranged from 11:11 to 11:14 AM, local time (Table 1). Landsat 7 and Landsat 8 have a pixel resolution of $30 \mathrm{~m}$ by $30 \mathrm{~m}$ in the shortwave bands and $60 \mathrm{~m}$ by $60 \mathrm{~m}$ and $100 \mathrm{~m}$ by $100 \mathrm{~m}$ in the thermal band, respectively.

The wedge-shaped gaps appearing within the Landsat 7 images as a result of the SLC-off issue were removed using the Imagine built-in focal analysis tool. During the process, the gap is filled iteratively based on information from nearby pixels. The gap filling is completed prior to image processing (http://landsat.usgs.gov/gap-filling-landsat-7-slc-singlescenes-using-erdas-imagine-TM) [48]. An example of the process is shown in Figure 2. 
TABLE 1: Day of year (DOY), selected acquisition dates, Landsat satellite, path/row, and overpass time during the 2016 corn growing season at standard time, used for $\mathrm{ET}_{\mathrm{a}}$ estimations.

\begin{tabular}{lcccc}
\hline DOY & Acquisition dates & Satellite & Path/row & Overpass time (local) \\
\hline 154 & $06 / 02 / 16$ & Landsat 8 & $29 / 29$ & $11: 11: 03$ AM \\
178 & $06 / 26 / 16$ & Landsat 7 & $29 / 29$ & $11: 13: 56$ AM \\
194 & $07 / 12 / 16$ & Landsat 7 & $29 / 29$ & $11: 13: 55$ AM \\
202 & $07 / 20 / 16$ & Landsat 8 & $29 / 29$ & $11: 11: 21$ AM \\
218 & $08 / 05 / 16$ & Landsat 8 & $29 / 29$ & $11: 11: 24$ AM \\
234 & $08 / 21 / 16$ & Landsat 8 & $29 / 29$ & $11: 11: 30$ AM \\
258 & $09 / 14 / 16$ & Landsat 7 & $29 / 29$ & $11: 14: 05$ AM \\
\hline
\end{tabular}

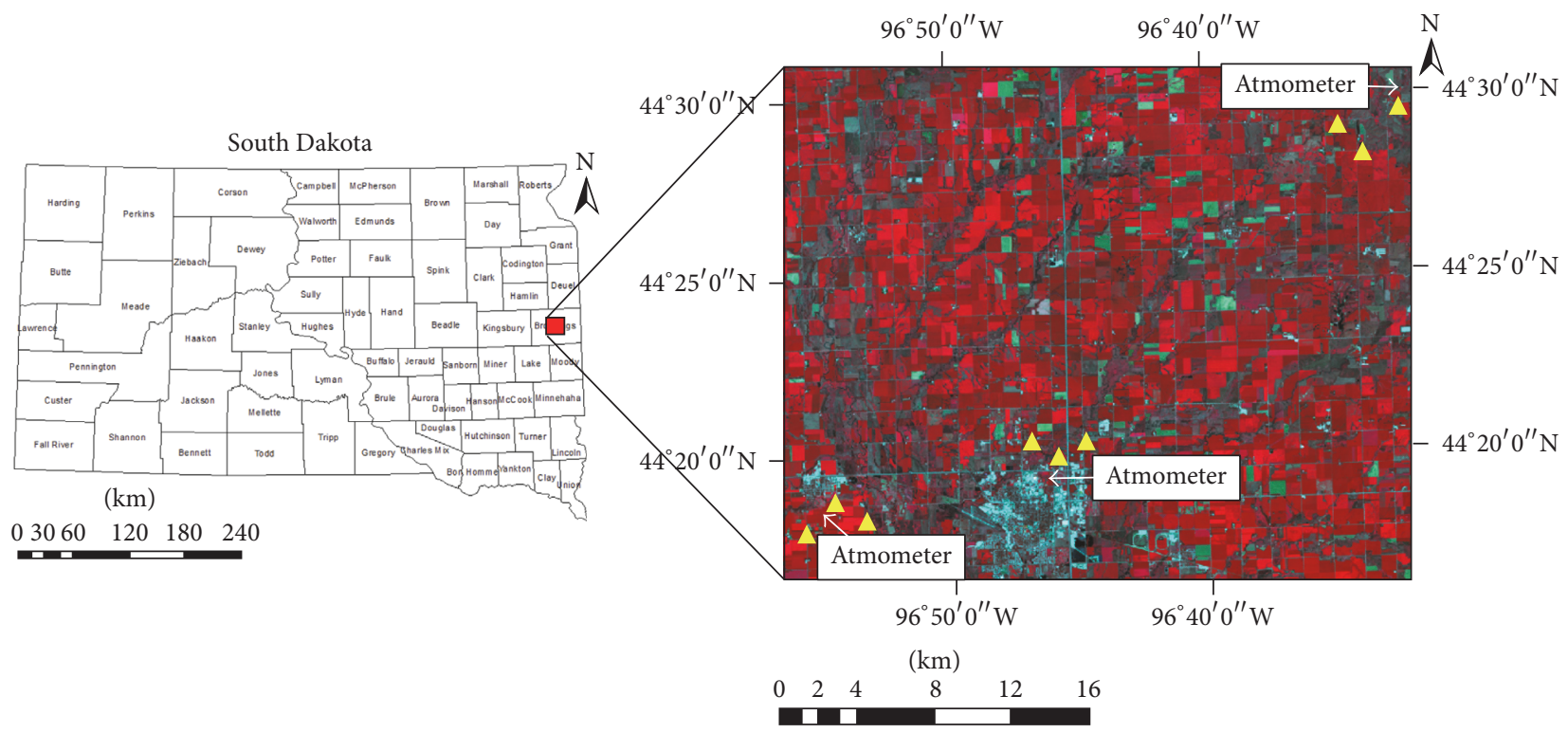

(a)

(b)

FIGURE 1: South Dakota with county boundaries: the red rectangle shows the study area in eastern South Dakota (a). Landsat 7 with false color composite (bands 4, 3, and 2) indicates the atmometer locations and the nine yellow triangles show corn field sites (b).

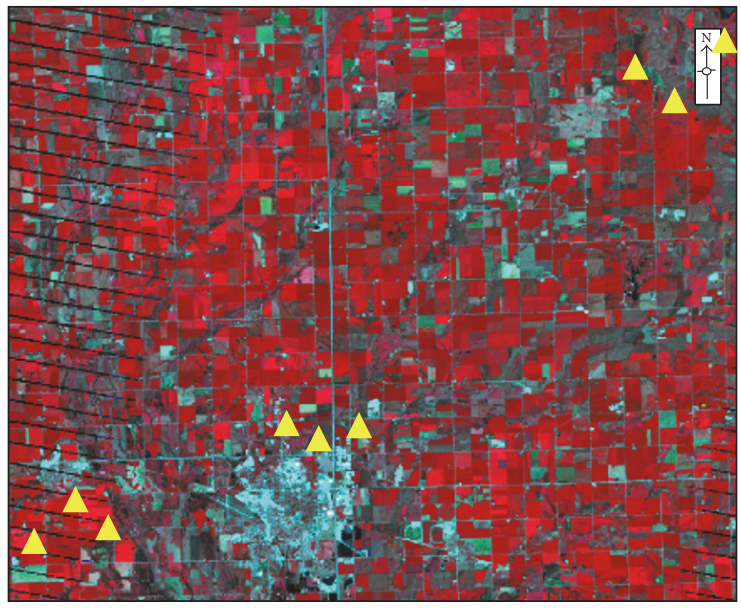

(a)

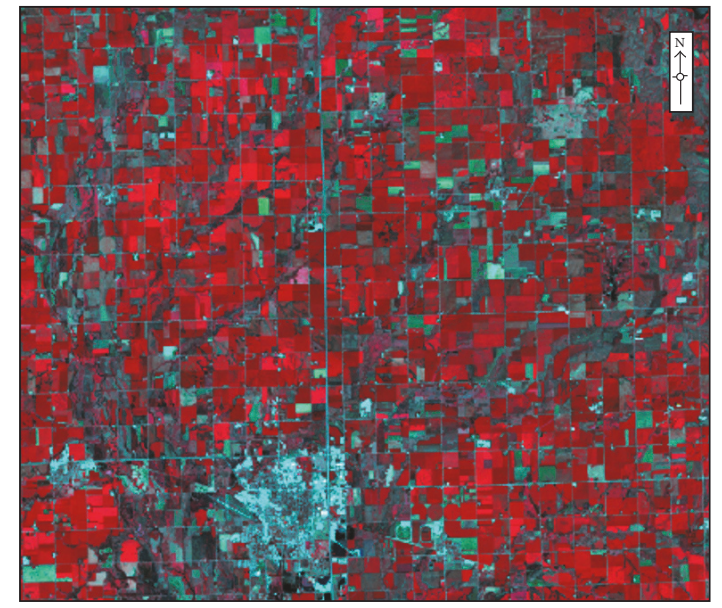

(b)

FIGURE 2: Stripes removed from Landsat 7 image. Original image with nine yellow triangles that indicate corn field sites (a) and final image without stripes, where SLC-off image is filled after employing the focal analysis tool two times (b). 
2.3. METRIC Model. $\mathrm{ET}_{\mathrm{a}}$ estimations use the METRIC model approach as described by Allen et al. $[1,6]$.

METRIC model is a remote sensing image processing model that computes instantaneous ET values as a residual of the surface energy balance equation $[1,6,49,50]$ :

$$
\mathrm{LE}=R_{n}-G-H,
$$

where LE is the latent heat flux $\left(\mathrm{W} \mathrm{m}^{-2}\right)$, or ET $\left(\mathrm{mm} \mathrm{day}^{-1}\right)$, $R_{n}$ is the net radiation $\left(\mathrm{W} \mathrm{m}^{-2}\right), G$ is the soil heat flux $\left(\mathrm{W} \mathrm{m}^{-2}\right)$, and $H$ is the sensible heat flux $\left(\mathrm{W} \mathrm{m}^{-2}\right)$.

Net radiation $\left(R_{n}\right)$ is calculated using surface reflectance and surface temperature $\left(T_{s}\right)$ derived by satellite imagery. $R_{n}$ is the difference between incoming shortwave radiation and outgoing longwave radiation computed as

$$
R_{n}=R_{S \downarrow}-\alpha R_{S \downarrow}+R_{L \downarrow}-R_{L \uparrow}-\left(1-\varepsilon_{o}\right) R_{L \downarrow},
$$

where $R_{S \downarrow}$ is the incoming shortwave radiation $\left(\mathrm{W} \mathrm{m}^{-2}\right)$ (solar radiation), $\alpha$ is surface albedo (dimensionless), $R_{L \downarrow}$ is the incoming longwave radiation $\left(\mathrm{W} \mathrm{m}^{-2}\right), R_{L \uparrow}$ is the outgoing longwave radiation $\left(\mathrm{W} \mathrm{m}^{-2}\right)$, and $\varepsilon_{o}$ is the surface thermal emissivity (dimensionless). $\left(1-\varepsilon_{o}\right) R_{L \downarrow}$ is the fraction of incoming longwave radiation reflected from the surface.

Soil heat flux $(G)$ is the magnitude of the heat flux stored or released into the soil. $G$ was computed using the following equations described by Tasumi [51]:

$$
\frac{G}{R_{n}}= \begin{cases}0.05+0.18 e^{-0.521 \mathrm{LAI}} & \mathrm{LAI} \geq 0.5 \\ \frac{1.80\left(T_{s}-273.16\right)}{R_{n}}+0.084 & \mathrm{LAI}<0.5\end{cases}
$$

Sensible heat flux $(H)$ was determined using the aerodynamic based heat transfer equation as follows:

$$
H=\rho_{\mathrm{air}} C_{p} \frac{d T}{r_{\mathrm{ah}}},
$$

where $\rho_{\text {air }}$ is the air density $\left(\mathrm{kg} \mathrm{m}^{-3}\right), C_{p}$ is the air specific heat $\left(1004 \mathrm{~J} \mathrm{~kg}^{-1} \mathrm{~K}^{-1}\right), d T$ is the temperature difference between two heights $z_{1}(0.1 \mathrm{~m})$ and $z_{2}(2 \mathrm{~m})$, and $r_{\text {ah }}$ is the aerodynamic resistance to heat transfer $\left(\mathrm{s} \mathrm{m}^{-1}\right)$.

For the $H$ estimations, the METRIC model uses the CIMEC (Calibration using Inverse Modeling of Extreme Conditions) procedure described by Bastiaanssen et al. [52] and Allen et al. [6] to calibrate the near surface to air temperature difference for each pixel within an image based on a regression relationship between $d T$ and $T_{s}$ of two anchor pixels (hot and cold). The advantage of the CIMEC approach within the METRIC model reduces possible impacts of biases in estimation of aerodynamic stability correction and surface roughness [6].

In this study, hot and cold pixels were selected for each image in agricultural fields near to the weather stations $(<15 \mathrm{~km})$. The hot pixel was selected in a bare agricultural field with no vegetation cover, while the cold pixel was selected in an agricultural field with full vegetation cover. An adjustment factor is used to adjust the ET estimation to reflect the actual evaporation amount at the cold and hot pixels. A value of 1.05 is typically used for the cold pixel but may be adjusted down in situations where the no field with vegetation cover is present within the image. For the hot pixel, a value of 0.05 is typically used for situations where the top $10-15 \mathrm{~cm}$ of the soil is dry and no rainfall has occurred for several weeks. The bare soil evaporation model by Allen et al. [8] was used to establish the appropriate adjustment factor higher than 0.05 to account for residual soil evaporation from antecedent rainfall.

Based on LE values, the instantaneous values of ET were computed for each pixel as

$$
\mathrm{ET}_{\text {inst }}=3600 \frac{\mathrm{LE}}{\lambda \rho w},
$$

where $\mathrm{ET}_{\text {inst }}$ is the hourly instantaneous ET $\left(\mathrm{mm} \mathrm{h}^{-1}\right), 3600$ is used to convert to hours, $\mathrm{LE}$ is the latent heat flux $\left(\mathrm{W} \mathrm{m}^{-2}\right)$ consumed by ET, $\rho w$ is the density of water $\left(1000 \mathrm{~kg} \mathrm{~m}^{-3}\right)$, and $\lambda$ is the latent heat of evaporation $\left(\mathrm{j} \mathrm{kg}^{-1}\right)$, which is computed as

$$
\lambda=\left(2.501-0.00236\left(T_{s}-273.15\right) \times 10^{6}\right) .
$$

The reference ET fraction $\left(\mathrm{ET}_{\mathrm{r}} \mathrm{F}\right)$ or crop coefficient $\left(K_{c}\right)$ was calculated based on $\mathrm{ET}_{\text {inst }}$ for each pixel and $\mathrm{ET}_{\mathrm{r}}$ was obtained from local weather data.

$$
\mathrm{ET}_{\mathrm{r}} \mathrm{F}=\frac{\mathrm{ET}_{\text {inst }}}{\mathrm{ET}_{\mathrm{r}}}
$$

Daily values of ET $\left(\mathrm{ET}_{24}\right)\left(\mathrm{mm} \mathrm{day}^{-1}\right)$ for each pixel were calculated as follows:

$$
\mathrm{ET}_{24}=\mathrm{ET}_{\mathrm{r}} \mathrm{F} \times \mathrm{ET}_{\mathrm{r}} 24,
$$

where $\mathrm{ET}_{\mathrm{r}} \mathrm{F}$ is the reference $\mathrm{ET}$ fraction, $\mathrm{ET}_{\mathrm{r}} 24$ is the cumulative alfalfa reference for the day $\left(\mathrm{mm} \mathrm{day}^{-1}\right)$, and $\mathrm{ET}_{24}$ is the actual evapotranspiration for the entire 24-hour period $\left(\mathrm{mm}\right.$ day $\left.^{-1}\right)$.

Monthly and seasonal $\mathrm{ET}_{\mathrm{a}}$ are calculated by interpolation daily values of $\mathrm{ET}_{\mathrm{r}} \mathrm{F}$ between images and multiplying by $\mathrm{ET}_{\mathrm{r}}$ for each day and then integrated over the specific month [6]. The interpolation values of $\mathrm{ET}_{\mathrm{r}} \mathrm{F}$ are made using a linear interpolation or a curvilinear interpolation function such as a spline function [53]. According to Allen et al. [6] one cloudfree satellite image per month is enough to develop $\mathrm{ET}_{\mathrm{r}} \mathrm{F}$ curves for seasonal $\mathrm{ET}_{\mathrm{a}}$ estimations.

2.4. Meteorological Data. Hourly weather data was used for the internal calibration of the METRIC model. The weather observations were taken from the automatic Brookings, Volga, and Oak Lake stations. All weather stations are located in Brookings County, SD. The weather stations at Brookings and Oak Lake sites are surrounded by grass, whereas the weather station at Volga is surrounded by corn fields.

The $\mathrm{ET}_{\mathrm{r}}$ values were calculated using weather dataset using the Penman-Monteith equation $[8,54]$ as follows:

$$
\begin{aligned}
& \mathrm{ET}_{\text {ref }} \\
& \quad=\frac{0.408 \Delta\left(R_{n}-G\right)+\gamma\left(C_{n} /(T+273)\right) u_{2}\left(e_{s}-e_{a}\right)}{\Delta+\gamma\left(1+C_{d} u_{2}\right)},
\end{aligned}
$$




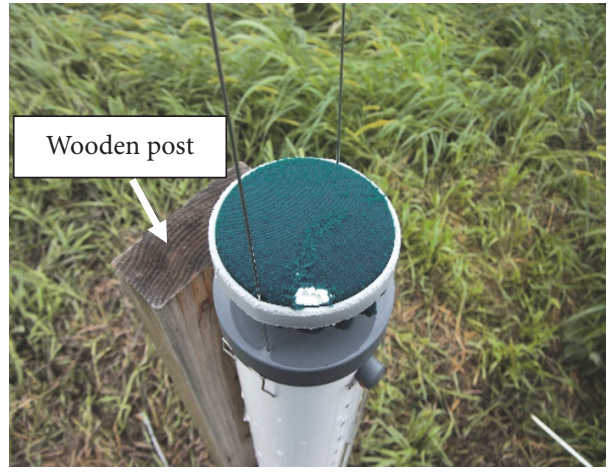

(a)

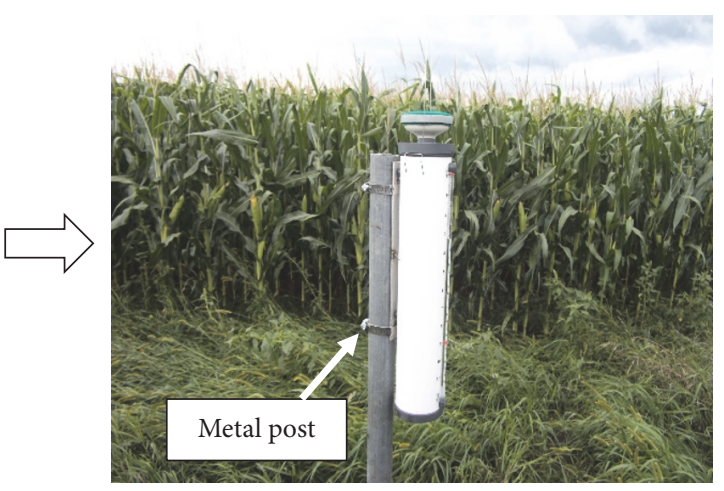

(b)

Figure 3: Atmometer mounted in wooden post damaged by mice (a) and mounted on a metal post (b) at Volga site.

where $\mathrm{ET}_{\text {ref }}$ is the alfalfa reference $\left(\mathrm{mm} \mathrm{day}^{-1}\right), \Delta$ is the slope pressure versus air temperature curve $\left(\mathrm{kPa}^{\circ} \mathrm{C}^{-1}\right), R_{n}$ is the net radiation at the crop surface $\left(\mathrm{MJ} \mathrm{m}^{-2}\right.$ day $\left.^{-1}\right), G$ is the soil heat flux at the soil surface $\left(\mathrm{MJ} \mathrm{m}{ }^{-2}\right.$ day $\left.^{-1}\right), T$ is the mean air temperature at 1.5 to $2.5 \mathrm{~m}$ height $\left({ }^{\circ} \mathrm{C}\right), u_{2}$ is the mean daily wind speed at $2 \mathrm{~m}$ height $\left(\mathrm{m} \mathrm{s}^{-1}\right), e_{s}$ is the saturation vapor pressure of the air $(\mathrm{kPa}), e_{a}$ is the actual vapor pressure of the air $(\mathrm{kPa}), \gamma$ is the psychrometric constant $\left(0.0671 \mathrm{kPa}^{\circ} \mathrm{C}^{-1}\right)$, $e_{s}-e_{a}$ is the vapor pressure deficit $(\mathrm{kPa}), C_{n}$ is the numerator constant $\left(1600 \mathrm{~K} \mathrm{~mm} \mathrm{~s}^{3} \mathrm{Mg}^{-1}\right.$ day $\left.^{-1}\right), C_{d}$ is the denominator constant $\left(0.38 \mathrm{~s} \mathrm{~m}^{-1}\right)$ for alfalfa reference, and 0.408 is the coefficient constant $\left(\mathrm{m}^{2} \mathrm{~mm} \mathrm{MJ}^{-1}\right)$.

All weather data were subjected to quality control (QC) prior to being used in any calculations as suggested by Allen et al. [8] and ASCE-EWRI [54]. Hourly QC included the following weather variables such as solar radiation, air temperature (maximum and minimum), wind speed, and air vapor pressure deficit. Therefore, accurate estimations of $\mathrm{ET}_{\mathrm{a}}$ depend on the quality weather data.

2.5. Atmometers. Three atmometers were used to measure daily $\mathrm{ET}_{\mathrm{r}}$. One automated atmometer Model E (ETgage Company, Loveland, Colorado, USA) was placed adjacent to the Oak Lake weather station. The automated atmometer Model E was connected to the automated Oak Lake weather station controlled by a CR1000 datalogger (Campbell Scientific, CSI, Logan, UT, USA), where the evaporated data were recorded every 5 minutes. Two manual atmometers were located adjacent to the Brookings and to the Volga weather stations, respectively. The target corn field was located within $5 \mathrm{~km}$ from the weather stations. Manual atmometers were manually recorded every morning between 8:15 and 8:30 AM at the Brookings and Volga sites, respectively. The evaporated water from the green canvas in manual atmometers was measured as the difference between the observed water levels on consecutive days [55].

All atmometers were covered with a number 54 green canvas which simulate evaporation rates of alfalfa reference crop. The atmometers were installed on a vertical wooden post using metal brackets and with the top of the ceramic evaporation surface $1.0 \mathrm{~m}$ above the ground surface. The atmometers were surrounded by grass at the Brookings and Oak Lake sites, while at the Volga site the atmometer was surrounded by rainfed corn fields $(<5 \mathrm{~m})$ in all directions. Due to rodent damage to the canvas, the wooden post at Volga site was replaced by a metal rod in early August (DOY 217) as shown in Figure 3 which prevented further damage and resulting loss of $\mathrm{ET}_{\mathrm{r}}$ data.

The atmometer observation period was from May 17, 2016 (DOY 138), to September 18, 2016 (DOY 262); during this period the atmometers were refilled two times with distilled water. Distilled water was used in the atmometer reservoir to prevent accumulation of solutes in and on the top of the plate that can decrease the porosity of the plate and affect the evaporation rates [34].

2.6. Development of Crop Coefficient $\left(K_{c}\right)$ Curves. $K_{c}$ curves were developed for each corn field at three sites based on the alfalfa reference crop coefficient using appendix E method from Manual 70 [3]. This method uses percent of time from planting to effective cover and days after effective cover to harvest for $K_{c}$ calculations. In our study, the effective cover for corn fields occurred around 55 days after emergence (DAE). Thus the effective cover was used such as a reference point to calculate local $K_{c}$ values. Local $K_{c}$ values for different corn growth stages were calculated and adjusted using DAE. According to Irmak et al. [56] the DAE is more accurate because it ignores the period prior to emergence and is more closely related to the corn growing period, from emergence until physiological maturity.

The $K_{c}$ curves generated in this study for different corn fields (Figure 6) were multiplied by the $\mathrm{ET}_{\mathrm{r}}$ obtained from atmometers to estimate $\mathrm{ET}_{\mathrm{a}}\left(\mathrm{ET}_{\mathrm{a}}\right.$-atm) and compare it with $\mathrm{ET}_{\mathrm{a}}$ estimated with the METRIC model (ET $\mathrm{a}$-METRIC).

2.7. Statistical Analysis between $E T_{a}-M E T R I C$ and $E T_{a}$-Atm. Statistical comparison between $\mathrm{ET}_{\mathrm{a}}$-METRIC and $\mathrm{ET}_{\mathrm{a}}$-atm was established using a simple linear regression. For the simple regression the model was $y=a+b x$, where $y$ is $\mathrm{ET}_{\mathrm{a}}$ atm and $x$ is $\mathrm{ET}_{\mathrm{a}}$-METRIC. Other statistical evaluations such as mean bias error (MBE) (see (10)), root mean square error (RMSE) (see (11)), coefficient of determination $\left(r^{2}\right)$ (see (12)), 

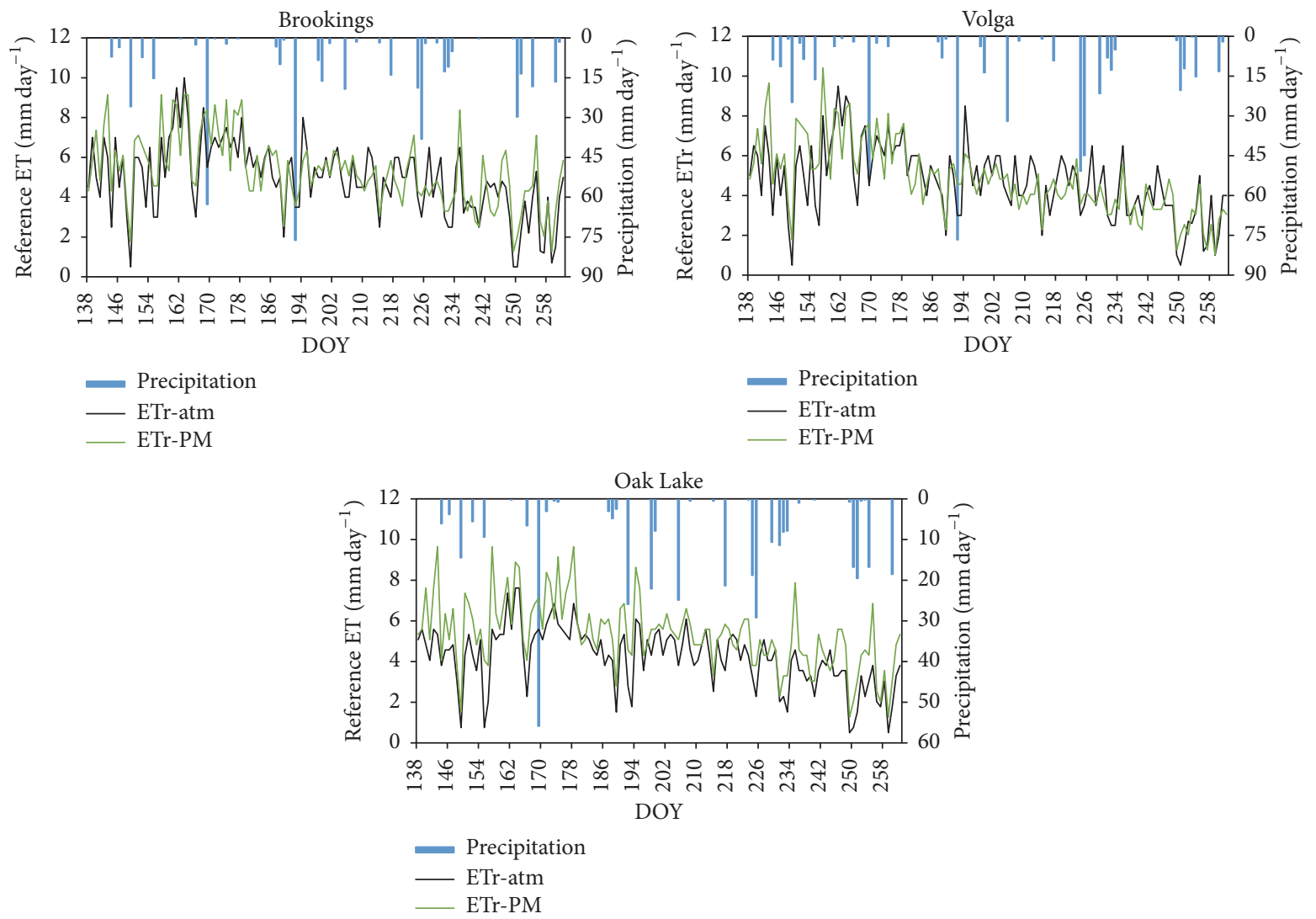

FIGURE 4: Daily $\mathrm{ET}_{\mathrm{r}}$ and precipitation for three different sites during the 2016 growing season in eastern South Dakota.

and Willmott index of agreement " $d$ " (see (13)) were used to determine agreement between $\mathrm{ET}_{\mathrm{a}}$-atm and $\mathrm{ET}_{\mathrm{a}}$-METRIC [57].

$$
\begin{aligned}
\mathrm{MBE} & =\frac{1}{n} \sum_{i=1}^{n}\left(x_{i}-y_{i}\right) \\
\mathrm{RMSE} & =\sqrt{\frac{1}{n} \sum_{i=1}^{n}\left(x_{i}-y_{i}\right)^{2}} \\
r^{2} & =\frac{\sum_{i=1}^{n}\left(x_{i}-\bar{x}\right)\left(x_{i}-\bar{y}\right)}{\sqrt{\sum_{i=1}^{n}\left(x_{i}-\bar{x}\right)^{2} \sum_{i=1}^{n}\left(y_{i}-\bar{y}\right)^{2}}} \\
d & =1-\frac{\sum_{i=1}^{n}\left(x_{i}-y_{i}\right)^{2}}{\sum_{i=1}^{n}\left(\left|x_{i}-\bar{x}\right|+\left|y_{i}-\bar{x}\right|\right)^{2}},
\end{aligned}
$$

where $n$ is the observation number, $x_{i}$ is the estimated value with the METRIC model, $y_{i}$ is estimated value using atmometer, and the bars above the variables indicate averages.

\section{Results and Discussion}

3.1. Precipitation and Reference Evapotranspiration $\left(E T_{r}\right)$. The cumulative precipitation values for the growing period were $450 \mathrm{~mm}, 497 \mathrm{~mm}$, and $380 \mathrm{~mm}$ for Brookings, Volga, and Oak Lake, respectively. In 2016 the cumulative precipitation for the three sites was greater than the average rain $( \pm 360 \mathrm{~mm})$ that typically falls during the growing season (April-October). The precipitation events had good distribution during the corn growing season due to the major events occurring in development stage, vegetation stage (V5) (June, 17), and tassel stage (VT) (July, 10) (Figure 4).

Daily values of $\mathrm{ET}_{\mathrm{r}}$ from atmometers $\left(\mathrm{ET}_{\mathrm{r}}\right.$-atm) varied from 0.5 to $10,0.5$ to 9.5 , and 0.5 to $7.6 \mathrm{~mm} \mathrm{day}^{-1}$ for Brookings, Volga, and Oak Lake, respectively (Figure 4). ET from Penman-Monteith equation $\left(\mathrm{ET}_{\mathrm{r}}-\mathrm{PM}\right)$ varied from 1.3 to $9.1 \mathrm{~mm} \mathrm{day}^{-1}$ for Brookings, 1.0 to $10.4 \mathrm{~mm} \mathrm{day}^{-1}$ for Volga, and 1.3 to $9.6 \mathrm{~mm} \mathrm{day}^{-1}$ for Oak Lake (Figure 4 ). The highest $\mathrm{ET}_{\mathrm{r}}$-atm values recorded in the three sites were in early June (DOY 161) and the lowest values were in early September (DOY 249). The highest $\mathrm{ET}_{\mathrm{r}}-\mathrm{PM}$ values registered in the three sites were in early June (DOY 157) and the lowest values were in middle of September (DOY 259). Even so, moderate correlations between $\mathrm{ET}_{\mathrm{r}}$-PM values and $\mathrm{ET}_{\mathrm{r}}$-atm values in the three sites were found with $r^{2}$ of $0.64,0.59$, and 0.67 for Brookings, Volga, and Oak Lake sites, respectively (Figure 5).

3.2. Development of Crop Coefficient $\left(K_{c}\right)$ Curves. The trends of $K_{c}$ for each corn field at three different sites during the growing season are shown in Figure 6. The $K_{c}$ curves showed similar tendencies for all corn fields, where $K_{c}$ values 

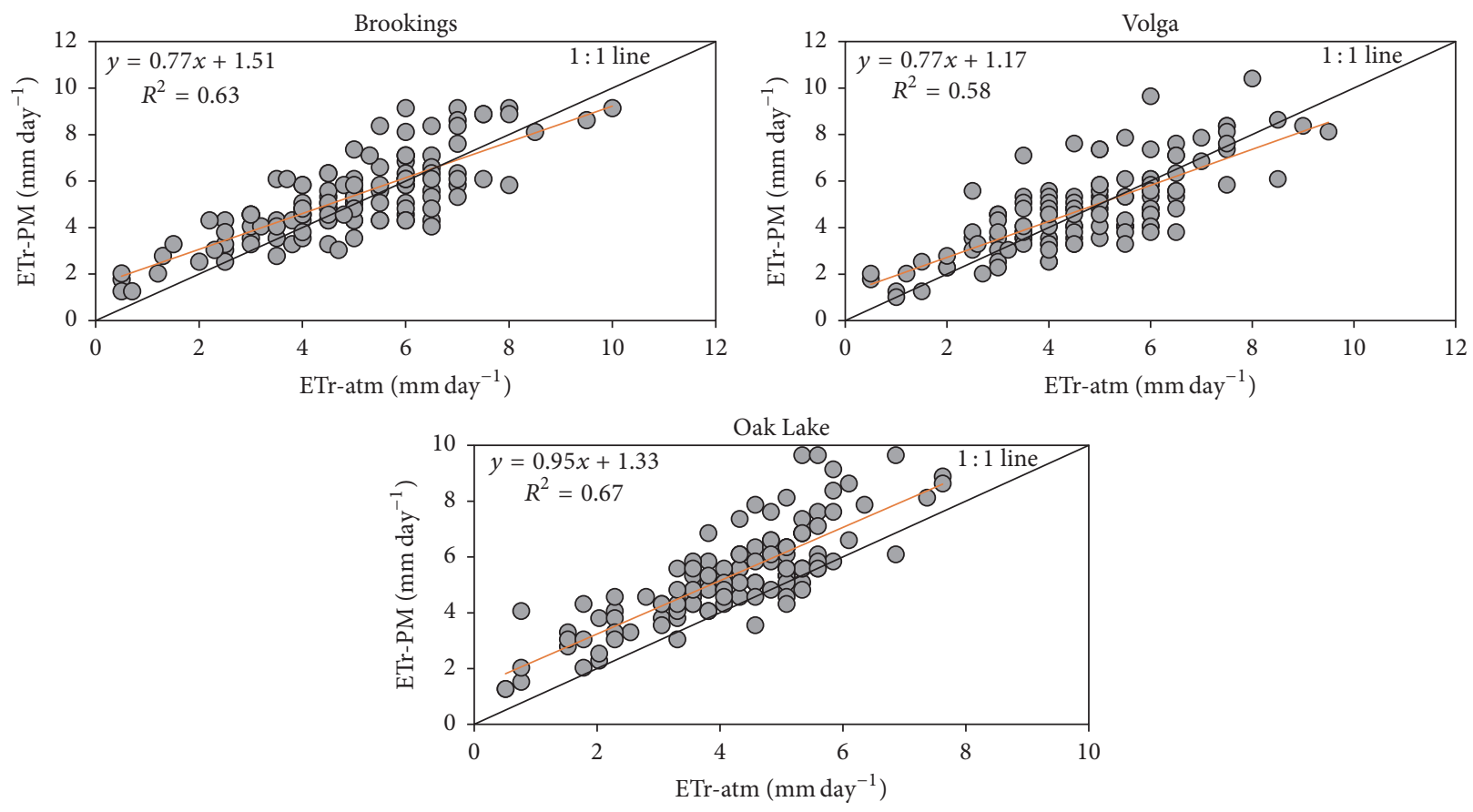

FIGURE 5: Relationship between $\mathrm{ET}_{\mathrm{r}}$-PM values and $\mathrm{ET}_{\mathrm{r}}$-atm values at the Brookings, Volga, and Oak Lake sites throughout the 2016 corn growing season.

increased from initial stage (vegetation stage (V3)) to midseason stage (VT). In this period the $K_{c}$ values increase as a function of time between $10 \%$ of crop cover to $100 \%$ of effective cover. In the mid-season the $K_{c}$ remains constant $\left(K_{c}=1.0\right)$, while in the late season the $K_{c}$ values gradually decreased indicating the crop senescence. At the end of the season (reproductive stage (R6)) the $K_{c}$ values are low again $\left(K_{c}= \pm 0.6\right)$.

The $K_{c}$ curves depend of vegetation index, soil water content, weather conditions, crop variety, and growing degree days $[8,56,58,59]$. In this study, $K_{c}$ curves for corn fields presented little variability because rainfall events, emergence days, and air temperature were almost homogenous in our study area.

The maximum $K_{c}$ values observed in this study were similar to the $K c_{r}$ (from alfalfa reference) values reported by Djaman and Irmak [58], who reported maximum $K c_{r}$ values from 50 to $70 \mathrm{DAE}$ in corn with rainfed treatment. Also, Wright [53] found maximum $K c_{r}$ values at the $100 \%$ of effective full cover for a corn field. However, our $K_{c}$ values are different from those reported by other researchers $[60,61]$. They found the peak $K c_{r}$ values $( \pm 1.0)$ from late July to early August ( \pm 70 DAE) for corn fields planted in south central Nebraska.

3.3. $E T_{a}$ Maps and Variation of ET $T_{a}$ throughout Growing Season. Spatial and temporal distribution of $\mathrm{ET}_{\mathrm{a}}$ maps during the growing season were generated by the METRIC model for Brookings, Volga, and Oak Lake (data not showed). However, Figure 7 shows two $\mathrm{ET}_{\mathrm{a}}$ maps for Brookings site, one $\mathrm{ET}_{\mathrm{a}}$ map displays high $\mathrm{ET}_{\mathrm{a}}$-METRIC value (dark blue color) in a corn field (white rectangle) at mid-season (DOY 194), and another $\mathrm{ET}_{\mathrm{a}}$ map shows low $\mathrm{ET}_{\mathrm{a}}$-METRIC value (light green color) at the end of the season (DOY 258). Generally, high ET rates are related to high crop water demands, which normally occurred in the mid-season period, while low ET rates occurred in early and late growing season when the crop has low vegetation and leaf senescence, respectively. Daily $\mathrm{ET}_{\mathrm{a}}$ maps helped to explain the variability of crop water requirements throughout the growing season.

The $\mathrm{ET}_{\mathrm{a}}$ maps developed by the METRIC model in this study were similar to other ET maps generated by the METRIC model and reported by Chávez et al. [13], Santos et al. [24], Folhes et al. [18], Droogers et al. [62], Healey et al. [15], Zhang et al. [20], and Carrillo-Rojas et al. [63], where they reported the spatial and temporal distribution of daily $\mathrm{ET}_{\mathrm{a}}$ for different crops including corn. In other situations, Chávez et al. [13] reported maximum $\mathrm{ET}_{\mathrm{a}}$ values $\left(14.1 \mathrm{~mm} \mathrm{day}^{-1}\right)$ due to high wind speed values $\left(7.0 \mathrm{~m} \mathrm{~s}^{-1}\right)$ at the time of satellite overpass in corn field in Texas High Plains, USA.

Figure 8 shows the variation of $\mathrm{ET}_{\mathrm{a}}$-METRIC values throughout the growing season at three sites. These results are in agreement with $[13,20,62]$; they reported high ET values at mid-season stage and low ET values at the end of the growing season in agricultural crops using the METRIC model.

3.4. ET $T_{a}$ Correlations between the METRIC Model and Atmometer. In the METRIC model ET a was taken from ten randomly selected pixels in three corn fields at three locations for each satellite image, while for the atmometer method $\mathrm{ET}_{\mathrm{a}}$ was the result of multiplying $\mathrm{ET}_{\mathrm{r}}$ (from atmometer) by $K_{c}$ values generated in this study for each corn field.

The linear relationship between $\mathrm{ET}_{\mathrm{a}}$-METRIC values and $\mathrm{ET}_{\mathrm{a}}$-atmometer $\left(\mathrm{ET}_{\mathrm{a}}\right.$-atm) values in three fields at three sites 

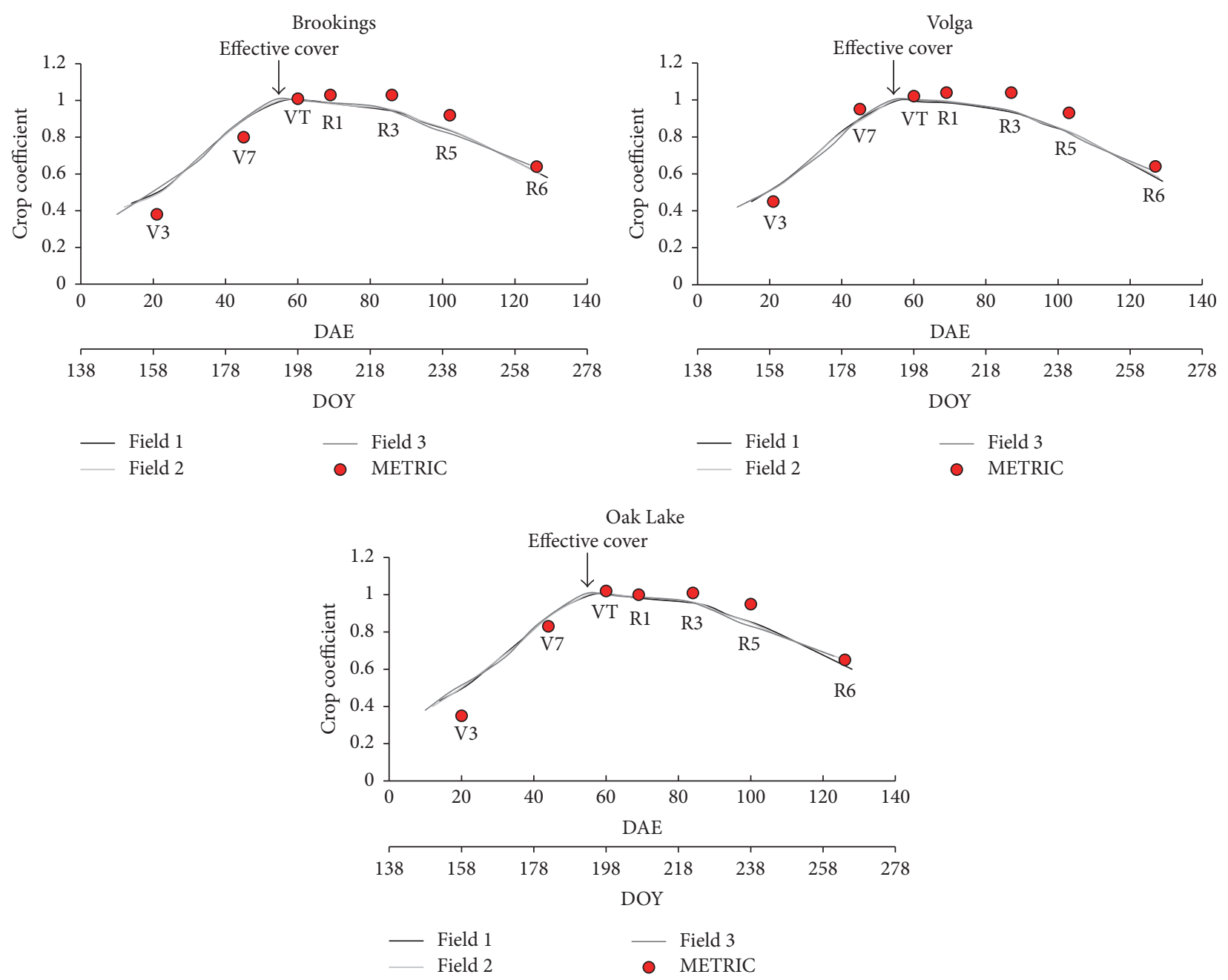

FIGURE 6: Crop coefficient curves based on the alfalfa reference crop coefficient in three fields at the Brookings, Volga, and Oak Lake sites. The red circles indicate the average $K_{c}\left(\mathrm{ET}_{\mathrm{r}} \mathrm{F}\right)$ values derived from the METRIC model.

TABLE 2: Regression coefficients between $\mathrm{ET}_{\mathrm{a}}$-METRIC values and $\mathrm{ET}_{\mathrm{a}}$-atm values for three corn fields at three sites.

\begin{tabular}{lccccccccc}
\hline Corn field & Slope & $\begin{array}{c}\text { Brookings } \\
\text { Intercept }\end{array}$ & $r^{2}$ & Slope & $\begin{array}{c}\text { Volga } \\
\text { Intercept }\end{array}$ & $r^{2}$ & Oak Lake \\
Slope & Intercept & $r^{2}$ \\
\hline Field 1 & 0.73 & 1.28 & 0.92 & 0.90 & 0.61 & 0.79 & 0.65 & 0.73 & 0.93 \\
Field 2 & 0.72 & 1.20 & 0.91 & 0.97 & 0.32 & 0.81 & 0.66 & 0.75 \\
Field 3 & 0.78 & 1.14 & 0.87 & 0.98 & 0.33 & 0.82 & 0.64 & 0.86 & 0.88 \\
\hline
\end{tabular}

is shown in Figure 9. Brookings and Volga sites demonstrated good distribution of points around the 1:1 line, whereas Oak Lake shows that the points were distributed below the $1: 1$ line; this means that $\mathrm{ET}_{\mathrm{a}}$-METRIC values were higher than $\mathrm{ET}_{\mathrm{a}}$ atm values except on DOY 154. Even so, strong relationships were observed for Brookings and Oak Lake, and a good relationship was observed for Volga (Table 2). In addition, the sum for all corn fields, the $\mathrm{ET}_{\mathrm{a}}$-METRIC values, and the $\mathrm{ET}_{\mathrm{a}}{ }^{-}$ atm values correlated well (Table 3 ).

In general, the difference between $\mathrm{ET}_{\mathrm{a}}$-METRIC $\left(5.36 \mathrm{~mm} \mathrm{day}^{-1}\right)$ and $\mathrm{ET}_{\mathrm{a}}$-atm $\left(4.95 \mathrm{~mm} \mathrm{day}^{-1}\right)$ at three sites was approximately $8 \%$. The coefficient of determination $\left(r^{2}\right)$ and index of agreement (" $d$ ") were 0.87 and 0.84 , respectively. The corresponding MBE was $0.41 \mathrm{~mm} \mathrm{day}^{-1}$ and RMSE was $0.65 \mathrm{~mm} \mathrm{day}^{-1}$ (Table 3). According to RMSE value, this can be acceptable assuming an average daily ET $_{\mathrm{a}}$-METRIC value of $5.36 \mathrm{~mm} \mathrm{day}^{-1}$ and average daily $\mathrm{ET}_{\mathrm{a}}$-atm value of $4.95 \mathrm{~mm} \mathrm{day}^{-1}$. The METRIC model has been tested with other methods for $\mathrm{ET}_{\mathrm{a}}$ estimation. In this study METRIC was compared to atmometers, where the relationship between them was good $\left(r^{2}=0.87\right)$ indicating that the METRIC model is a useful tool to estimate $\mathrm{ET}_{\mathrm{a}}$ at field scale. It should 


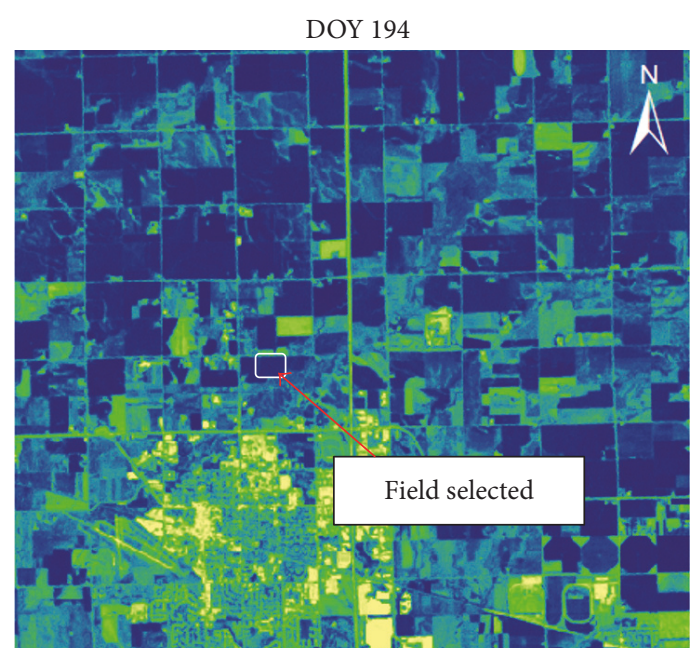

(Miles)

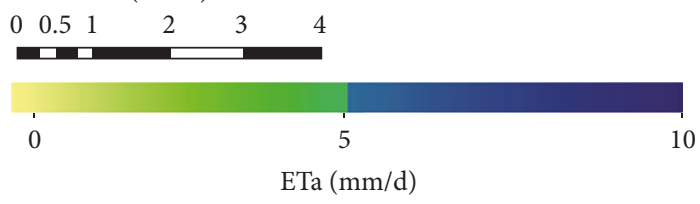

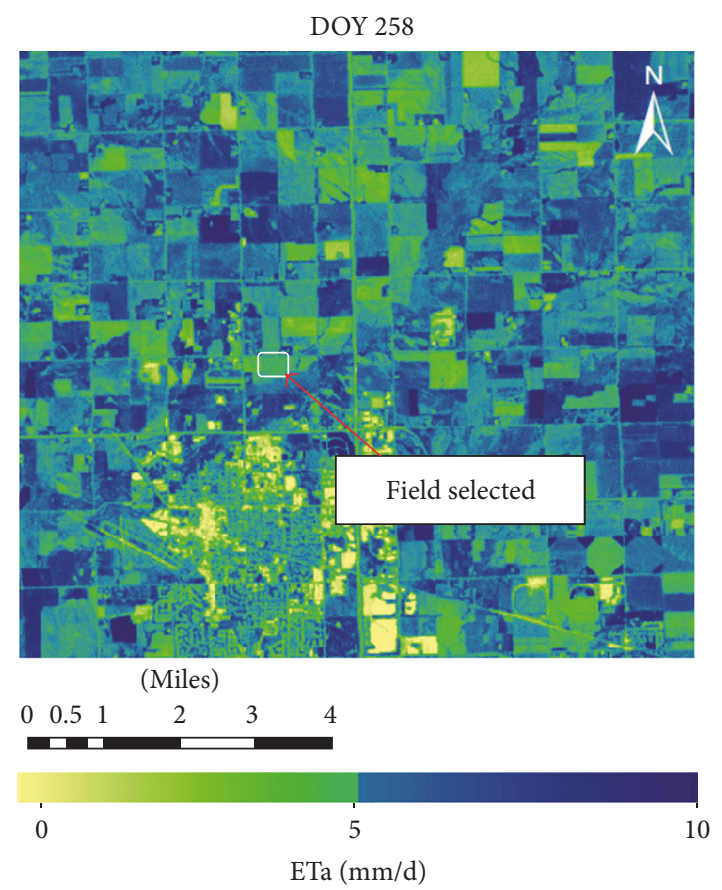

FIGURE 7: ET $\mathrm{a}$ maps developed by the METRIC model. White small rectangles show the corn field selected on DOY 194 and DOY 258. These dates showed high and low $\mathrm{ET}_{\mathrm{a}}$-METRIC values throughout the 2016 growing season at the Brookings site.

TABLE 3: Statistics comparing between $\mathrm{ET}_{\mathrm{a}}$-METRIC and $\mathrm{ET}_{\mathrm{a}}$-atm at the Brookings, Volga, and Oka Lake sites.

\begin{tabular}{|c|c|c|c|c|c|c|}
\hline Site & $\mathrm{ET}_{\mathrm{a}}-\operatorname{METRIC}\left(\mathrm{mm} \mathrm{day}^{-1}\right)$ & $\mathrm{ET}_{\mathrm{a}}-\operatorname{atm}\left(\mathrm{mm}\right.$ day $\left.^{-1}\right)$ & $\operatorname{MBE}\left(\mathrm{mm} \mathrm{day}^{-1}\right)$ & RMSE $\left(\mathrm{mm} \mathrm{day}^{-1}\right)$ & $r^{2}$ & "d" \\
\hline Brookings & 5.71 & 5.44 & 0.27 & 0.56 & 0.89 & 0.91 \\
\hline Volga & 4.88 & 5.07 & -0.19 & 0.91 & 0.81 & 0.89 \\
\hline Oak Lake & 5.50 & 4.35 & 1.15 & 0.48 & 0.90 & 0.73 \\
\hline Average & 5.36 & 4.95 & 0.41 & 0.65 & 0.87 & 0.84 \\
\hline
\end{tabular}

be noted that the comparison between METRIC and the atmometers was done for cloud-free conditions. While daily ETrF values are generated from METRIC enabling the construction of daily ET estimates throughout the growing season, those values were not part of this analysis.

Similar results in $r^{2}( \pm 0.86)$ were reported by Healey et al. [15], Morton et al. [64], Gordillo et al. [19], French et al. [28], and Liebert et al. [21], who compared ET $\mathrm{a}_{\mathrm{a}}$ estimated with the METRIC model and $\mathrm{ET}_{\mathrm{a}}$ measured with Bowen Ratio Energy Balance System (BREBS) and Eddy Covariance (EC) methods. Similar results $\left(r^{2}= \pm 0.85\right)$ were found in $\mathrm{ET}_{\mathrm{r}}$ measured with atmometers by other researchers [32, 65], although different $\mathrm{ET}_{\mathrm{r}}$ results (low $r^{2}= \pm 0.70$ ) were reported by Chen and Robinson [66] and Lamine et al. [41]. All these authors compared $\mathrm{ET}_{\mathrm{r}}$ measured using atmometer covered with a No 54 green canvas (alfalfa reference) with $\mathrm{ET}_{\mathrm{r}}$ estimated using agrometeorological data under different weather conditions.

3.5. ET $T_{a}$ Differences between the METRIC Model and Atmometer. The difference between the daily $\mathrm{ET}_{\mathrm{a}}$ estimated with the METRIC model (ET $\mathrm{a}_{\mathrm{a}}$ METRIC) and $\mathrm{ET}_{\mathrm{a}}$ estimated by atmometer $\left(\mathrm{ET}_{\mathrm{a}}\right.$-atm) is presented in Figure 10. Negative values indicated that the $\mathrm{ET}_{\mathrm{a}}$-METRIC estimates are lower than $\mathrm{ET}_{\mathrm{a}}$-atm, while positive values indicated that the $\mathrm{ET}_{\mathrm{a}}$ METRIC estimates exceed $\mathrm{ET}_{\mathrm{a}}$-atm.

In Brookings, the daily $\mathrm{ET}_{\mathrm{a}}$ difference ranged from -0.95 to $1.32 \mathrm{~mm} \mathrm{day}^{-1}$, found in field 1 (DOY 154) (V3) and field 2 (DOY 202) (R1), respectively. The more negative values were presented early in the growing season (DOY 154) (V3) due to high $K_{c}$ value $(0.51)$ used with atmometer method compared to the low $K_{c}$ value (0.38) used in the METRIC model method. In addition, on DOY 178 (V7) corn field 3 shows negative value $\left(-0.4 \mathrm{~mm} \mathrm{day}^{-1}\right)$; this is attributed to hailstorm, which occurred on DOY 169 (V5) nine days before that satellite image overpass. The high positive values (DOY 178,194 , and 202) were related to high wind speed values $\left(>4 \mathrm{~m} \mathrm{~s}^{-1}\right)$ at the time of satellite overpass (red columns in Figure 12). On DOY 218, 234, and 258 the difference between $\mathrm{ET}_{\mathrm{a}}$-METRIC and $\mathrm{ET}_{\mathrm{a}}$-atm was small $\left( \pm 0.5 \mathrm{~mm}_{\text {day }}{ }^{-1}\right)$.

At the Volga site, the daily $\mathrm{ET}_{\mathrm{a}}$ difference varied between -1.93 and $1.33 \mathrm{~mm} \mathrm{day}^{-1}$. These values were found in field 1 for DOY 194 (VT) and for DOY 178 (V7), respectively. The higher positive values were during the development stage 

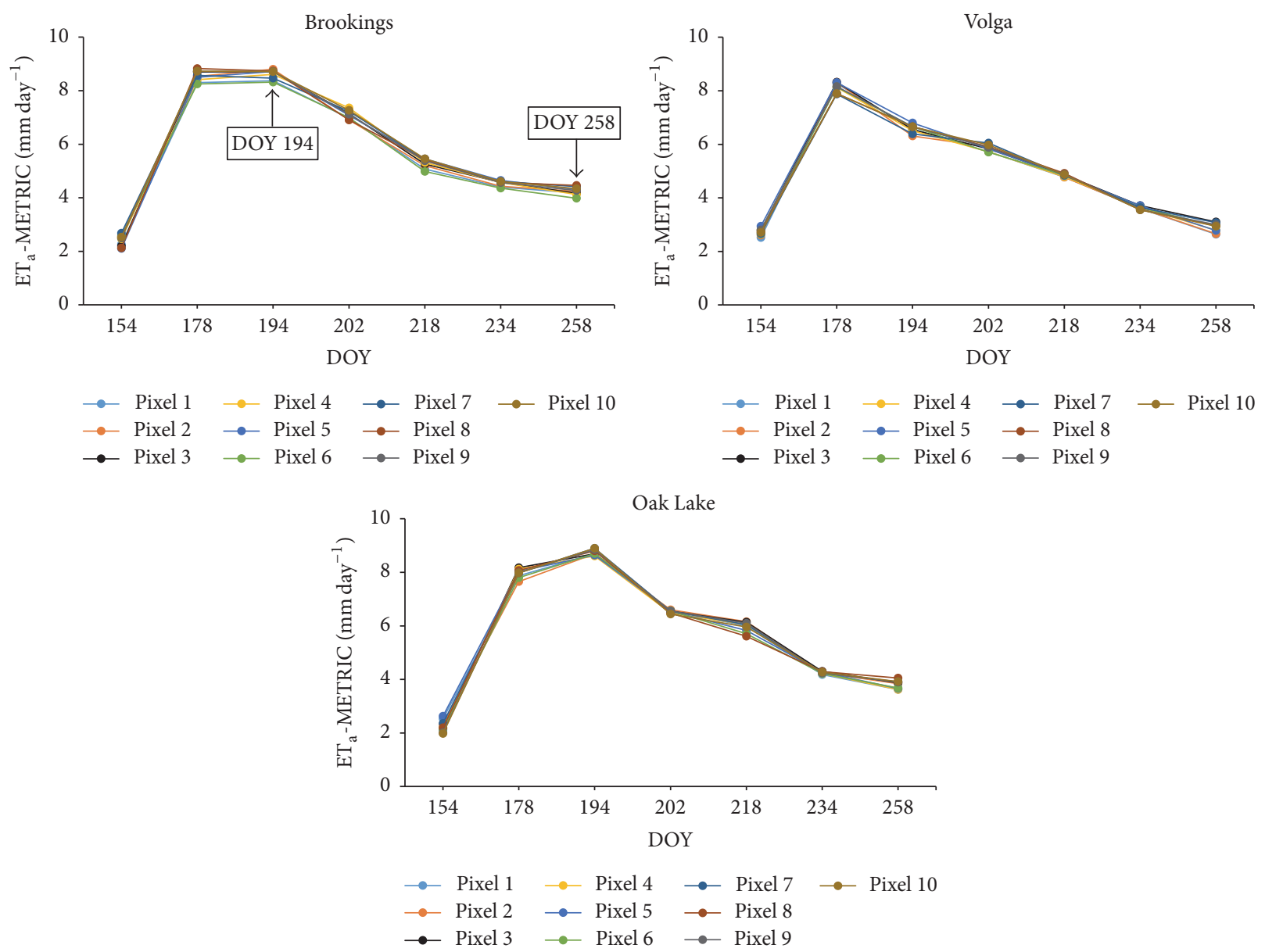

FIgURE 8: Evolution of $\mathrm{ET}_{\mathrm{a}}$-METRIC values at three sites in eastern South Dakota. Ten random pixels were selected within a field in each site. The values from those same pixels were observed during the 2016 growing season.

(DOY 178) (V7) when the corn was $1 \mathrm{~m}$ tall. The lower negative values were during the mid-season (DOY 194) (VT) when the crop was $2 \mathrm{~m}$ tall. This discrepancy was due to not only the wind speed values but also $\mathrm{ET}_{\mathrm{r}}$ recorded in atmometer on DOY 194 (VT). The $\mathrm{ET}_{\mathrm{r}}$ recorded in this date was one of the highest values registered during the corn growing season (Figure 4, Volga). After DOY 202 (R1) the difference between $\mathrm{ET}_{\mathrm{a}}$-METRIC and $\mathrm{ET}_{\mathrm{a}}$-atm was minimal $\left(<0.6 \mathrm{~mm} \mathrm{day}^{-1}\right)$, because daily average wind speed values were less than $0.8 \mathrm{~m} \mathrm{~s}^{-1}$ and $\mathrm{ET}_{\mathrm{r}}-\mathrm{PM}$ were around of $10 \%$ lower than the $\mathrm{ET}_{\mathrm{r}}$-atm. It is important to mention that at the Volga site the weather station was surrounded by corn fields $2 \mathrm{~m}$ tall and the wind speed is reduced by the corn height. So, when low wind speed is used to estimate $\mathrm{ET}_{\mathrm{r}}$ using the $\mathrm{P}-\mathrm{M}$ equation, the resulting $\mathrm{ET}_{\mathrm{r}}$ are too low. For this reason the wind speed did not affect the $\mathrm{ET}_{\mathrm{a}}$ difference between $\mathrm{ET}_{\mathrm{a}}$-METRIC and $\mathrm{ET}_{\mathrm{a}}$-atm from mid-season to late-season period.

At the Oak Lake site, the daily $\mathrm{ET}_{\mathrm{a}}$ difference ranged from -0.62 to $2.61 \mathrm{~mm} \mathrm{day}^{-1}$, reported for field 3 (DOY 154) (V3) and for field 1 (DOY 194) (VT), respectively. The negative values were found on DOY 154 (V3) for the three fields; this is attributed to that fact that the $\mathrm{ET}_{\mathrm{a}}$-atm was calculated using $K_{c}$ equal to 0.5 , while $\mathrm{ET}_{\mathrm{a}}$-METRIC used $K_{c}\left(\mathrm{ET}_{\mathrm{r}} \mathrm{F}\right)$ equal to 0.35 , indicating an overestimation of $30 \%$ with $\mathrm{ET}_{\mathrm{a}^{-}}$ atm method. The higher positive (overestimated) values were observed on DOY 194 (VT) (2.61 $\mathrm{mm} \mathrm{day}^{-1}$ ). At the Oak Lake site, the $\mathrm{ET}_{\mathrm{a}}$-METRIC values tend to be higher than the $\mathrm{ET}_{\mathrm{a}}$ atm values in almost all corn growing season. This noticeable difference is due to the high wind speed values registered throughout the growing season. These high values of wind speed may be attributed to the elevation of the weather station ( $574 \mathrm{~m}$ above sea level), which is $13 \%$ higher than Brookings and Volga elevations. Also, at the Oak Lake site the weather station and automated atmometer were located in smooth hill. On the other hand, we observed different $\mathrm{ET}_{\mathrm{a}}$ values on DOY 178 (V7) between corn fields. This difference is attributed to hailstorm, which affected the canopy cover in the fields 2 and 3 (Figure 10, Oak Lake).

Similar $\mathrm{ET}_{\mathrm{a}}$ differences were found by Choi et al. [26], who reported ET difference between -2.2 and $2.5 \mathrm{~mm}^{-1}$ day $^{-1}$ for different land cover types using METRIC model and trapezoid interpolation model (TIM). They found high discrepancy in ET due to low values of elevation; also they reported that as elevation increases the TIM model slightly overestimates the METRIC ET. On the contrary, low ET 

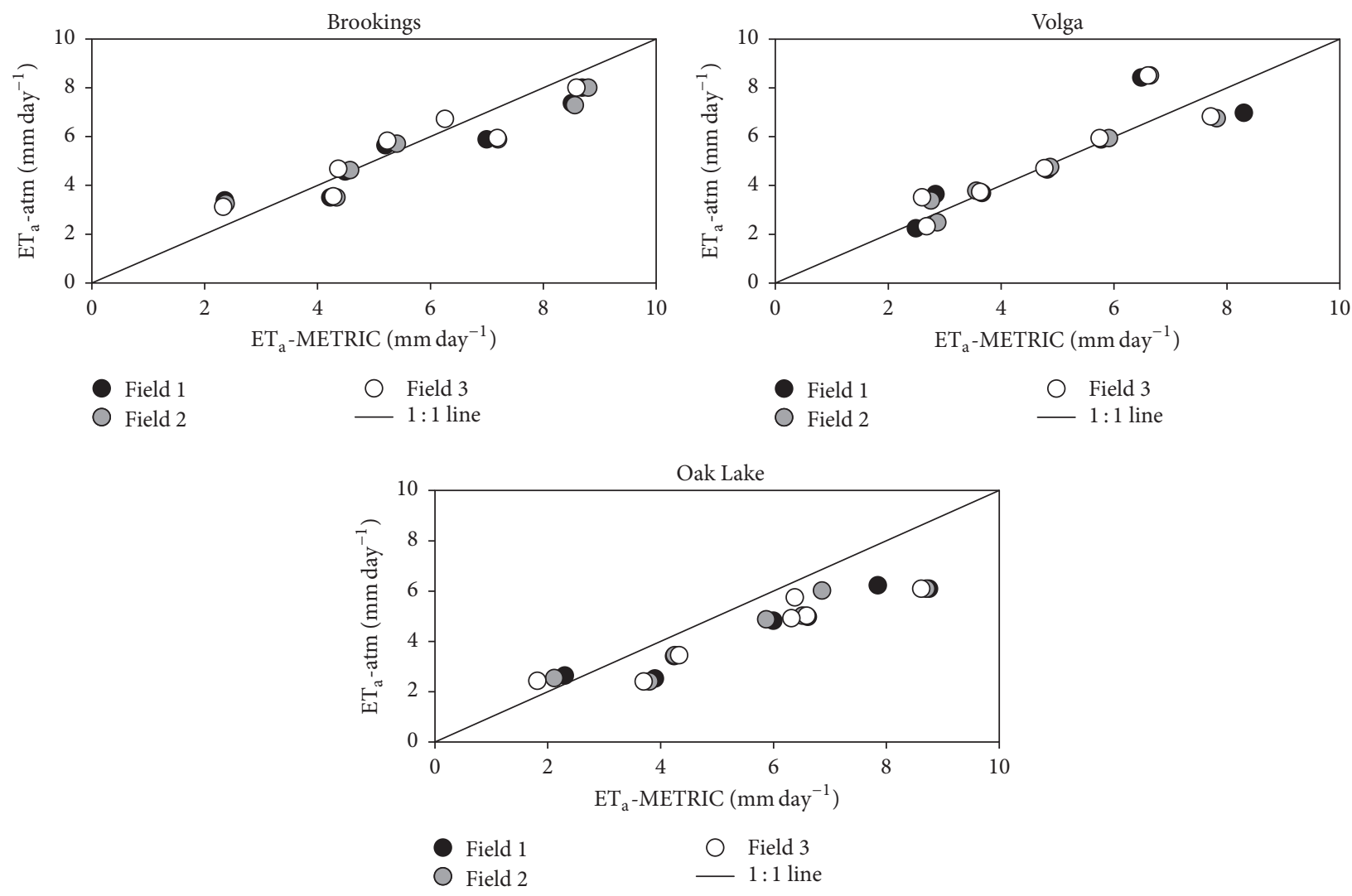

FIGURE 9: Relationship between $\mathrm{ET}_{\mathrm{a}}$-METRIC and $\mathrm{ET}_{\mathrm{a}}$-atm at three sites and nine corn fields in eastern South Dakota for the 2016 growing season. The black line represents the $1: 1$ line.

difference $\left( \pm 1.0 \mathrm{~mm} \mathrm{day}^{-1}\right)$ was reported by Chávez et al. [13], who compare ET estimated by METRIC and ET derived from soil water balance in irrigation corn in Texas. Also, Healey et al. [15] and Hankerson et al. [16] reported that ET difference ranged from -1.0 to $1.0 \mathrm{~mm}_{\text {day }}{ }^{-1}$ between the METRIC model and BREBS method in different crops.

In our study, daily $\mathrm{ET}_{\mathrm{a}}$ differences were attributed to high wind speed values $\left(>4 \mathrm{~m} \mathrm{~s}^{-1}\right)$ at time of satellite overpass. Generally, as the wind speed increases, the $\mathrm{ET}_{\mathrm{a}}$ difference increases (Figure 11). Figure 11 shows that at the Volga site (columns with dark gray color) the difference between $\mathrm{ET}_{\mathrm{a}}$ METRIC and $\mathrm{ET}_{\mathrm{a}}$-atm was minimal after mid-season stage; however at the Oak Lake site (black columns) the difference was major due to high wind speed.

3.6. Hourly Wind Speed at Three Sites. Hourly average wind speed $\left(\mathrm{m} \mathrm{s}^{-1}\right)$ for each overpass date at the Brookings, Volga, and Oak Lake sites is shown in Figure 12. The wind speed recorded at Volga is similar to Brookings and Oak Lake early in the season but then is quite a bit lower later during the growing season. This is because Volga weather station is too close to the corn fields, and the wind speed is reduced by the height of corn crop. On the contrary, at the Oak Lake site higher average wind speed values were found, especially at time of satellite overpass (red column in Figure 12). Also, the Oak Lake weather station recorded the maximum wind speed values throughout the season.
In Maui Island, USA, for example, Anderson et al. [67] and Zhang et al. [20] reported high variation in evapotranspiration due to high wind speeds values in sugarcane fields. Our results are similar to results reported by Westerhoff [68], who found that as the wind speed increases the $\mathrm{ET}_{\mathrm{a}}$ values slightly increase. In addition, Gleason et al. [65] reported ET underestimation with high wind speed conditions. Mokhtari et al. [69] reported that as the wind speed increases $\mathrm{ET}_{\mathrm{a}}$ decreases; also they concluded that the METRIC-based ET is highly sensitive to surface temperature but less sensitive to wind speed values.

Based on the results from our study, $\mathrm{ET}_{\mathrm{r}}$ values from atmometer need to be adjusted during the windy days. The adjustment factors (average ratio of $\mathrm{ET}_{\mathrm{r}}$-atm to $\mathrm{ET}_{\mathrm{r}}$ METRIC) for Brookings, Volga, and Oak Lake were 0.83, 0.87 , and 0.68 , respectively. These adjustment factors can be used to adjust the $\mathrm{ET}_{\mathrm{r}}$-atm values to get close estimates to the $\mathrm{ET}_{\mathrm{r}}-\mathrm{PM}$ values on windy days $\left(>4 \mathrm{~m} \mathrm{~s}^{-1}\right)$. These adjustment factors are necessary to correct $\mathrm{ET}_{\mathrm{r}}$-atm values to obtain accurate $\mathrm{ET}_{\mathrm{a}}$ estimations. On the other hand, $\mathrm{ET}_{\mathrm{r}}$ measured with atmometer can be used by the METRIC model instead of $\mathrm{ET}_{\mathrm{r}}$ derived from weather data for estimating $\mathrm{ET}_{\mathrm{a}}$.

\section{Conclusions}

The objective was to compare $\mathrm{ET}_{\mathrm{a}}$ estimated from satellitebased remote sensing METRIC model to $\mathrm{ET}_{\mathrm{a}}$ estimated with atmometers. 

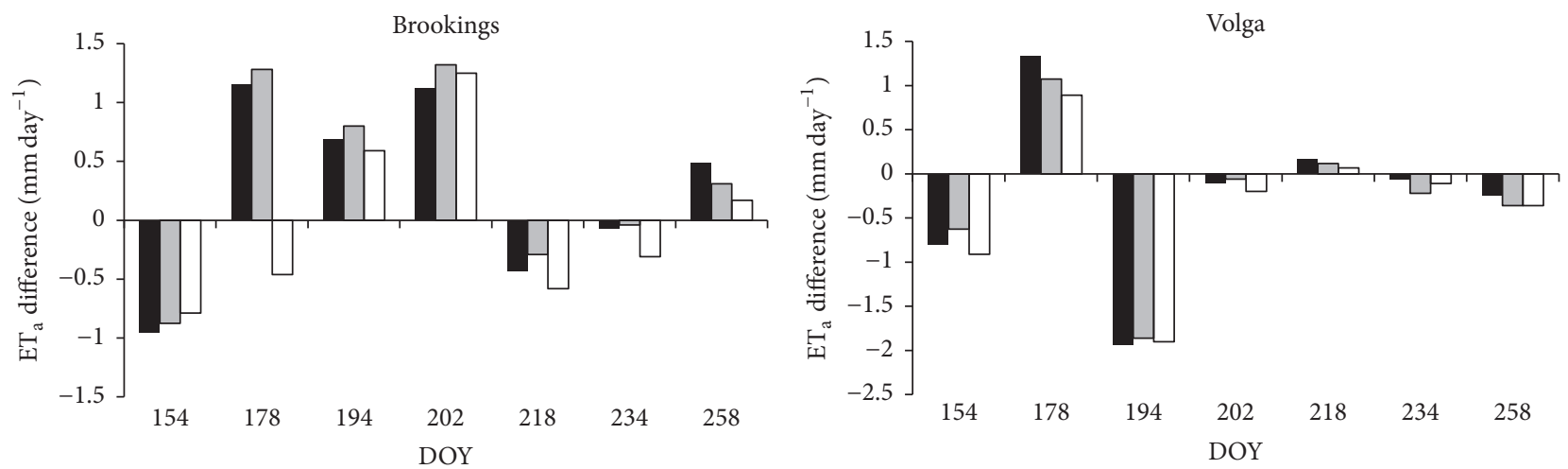

a Field 1

口 Field 2

- Field 1

$\square$ Field 2

$\square$ Field 3

$\square$ Field 3

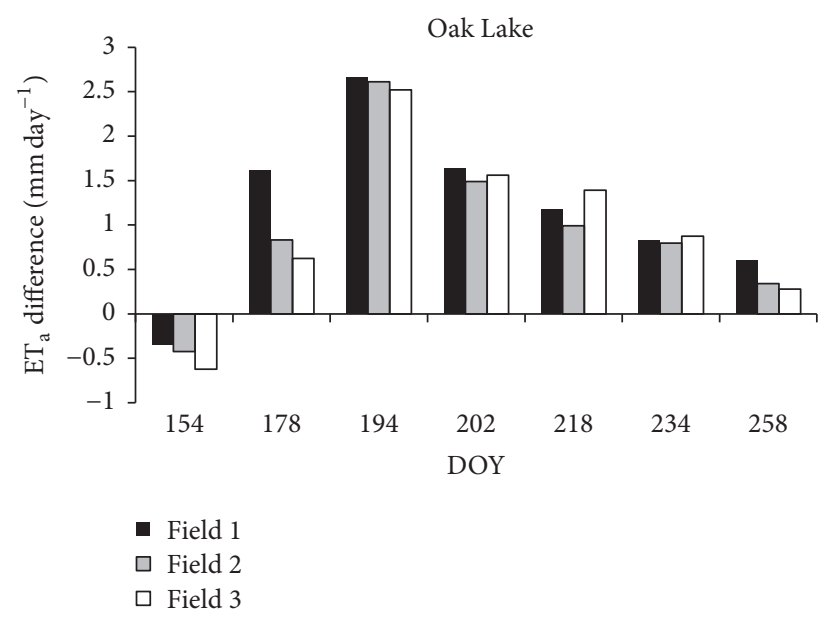

FIGURE 10: Daily $\mathrm{ET}_{\mathrm{a}}$ difference between $\mathrm{ET}_{\mathrm{a}}$-METRIC and $\mathrm{ET}_{\mathrm{a}}$-atm at three different sites throughout the 2016 corn growing season.

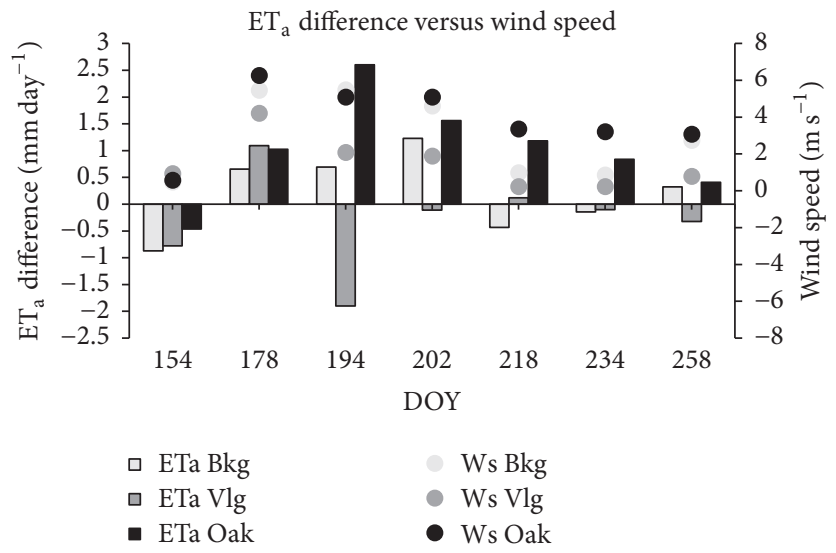

FIGURE 11: Comparison between average $\mathrm{ET}_{\mathrm{a}}$ difference and 3-hour average wind speed values at time of satellite overpass at three sites in eastern South Dakota. The columns indicate $\mathrm{ET}_{\mathrm{a}}$ difference values and the circles indicate wind speed values.

Spatial and temporal $\mathrm{ET}_{\mathrm{a}}$ values were observed at different crop growth stages using the METRIC model. The $\mathrm{ET}_{\mathrm{a}}$ values derived from METRIC were higher than $\mathrm{ET}_{\mathrm{a}}$ values estimated with atmometers. However, the $\mathrm{ET}_{\mathrm{a}}{ }^{-}$ METRIC and $\mathrm{ET}_{\mathrm{a}}$-atm correlated well with coefficient of determination $\left(r^{2}\right)$ of 0.87 and index of agreement (" $d$ ") of 0.84 . The main difference in $\mathrm{ET}_{\mathrm{a}}$ estimation with both methods was attributed to high wind speed values $\left(>4 \mathrm{~m} \mathrm{~s}^{-1}\right)$ at the time of satellite image overpass. According to our results, the $\mathrm{ET}_{\mathrm{r}}$-atm values need to be 

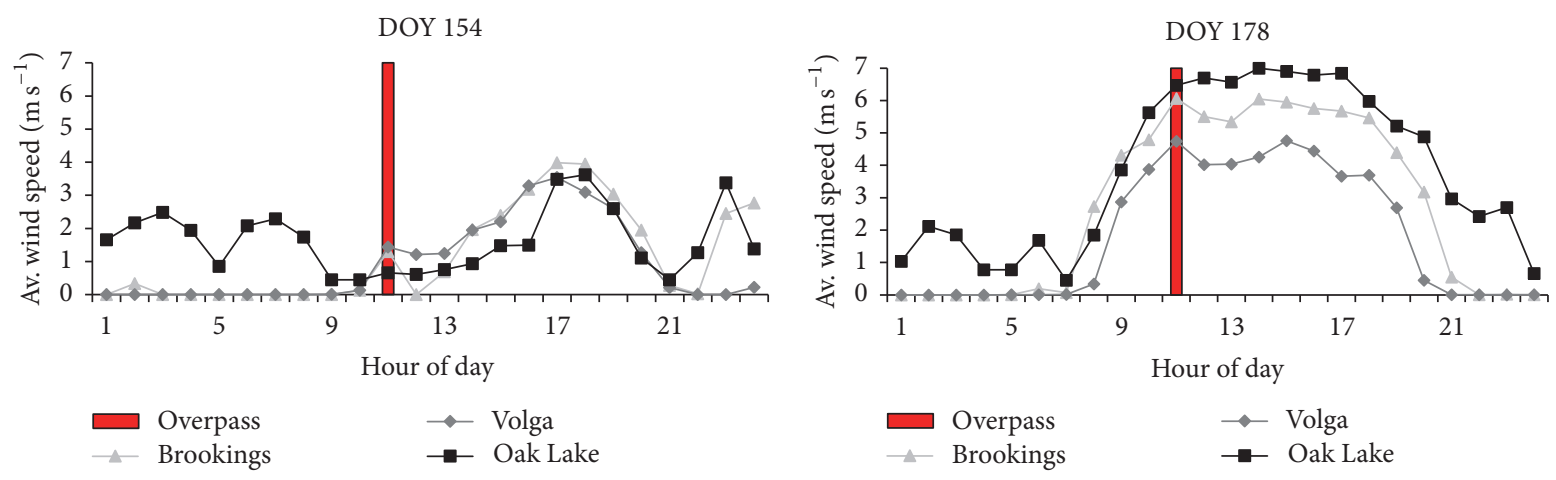

DOY 194
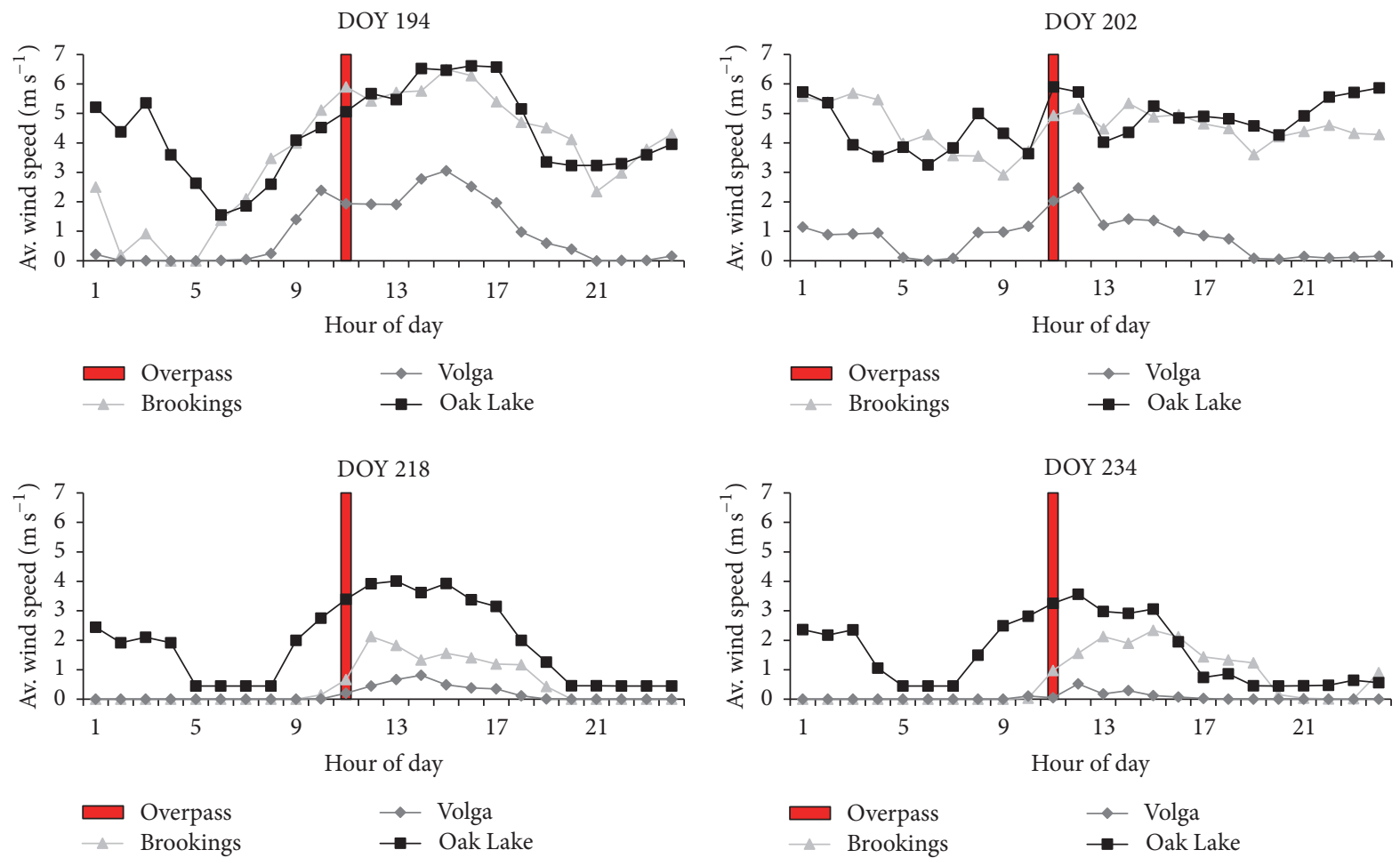

DOY 258

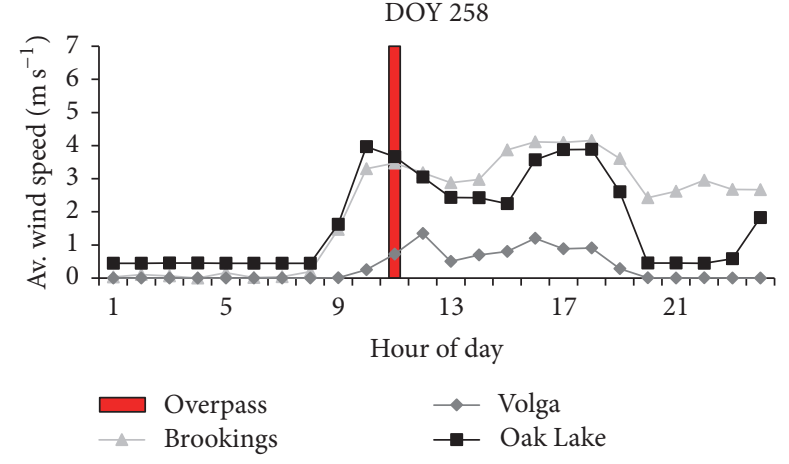

FIGURE 12: Hourly average wind speed values at three sites in eastern South Dakota. The red columns denote the time of satellite overpass $( \pm 11: 12$ AM).

adjusted during the windy days to get close estimates to the $\mathrm{ET}_{\mathrm{r}}-\mathrm{PM}$ values to get accurate $\mathrm{ET}_{\mathrm{a}}$ estimations. In this study adjusted $\mathrm{ET}_{\mathrm{r}}$-atm values were not validated.
Based on our results the METRIC model was sensible to wind speed values at the time of satellite overpass. A limitation of satellite derived ET is that $\mathrm{ET}_{\mathrm{a}}$ is estimated only for clear sky days, while $\mathrm{ET}_{\mathrm{a}}$ from atmometer is estimated 
for any weather condition. However, a limitation of $\mathrm{ET}_{\mathrm{a}}$ from atmometer is that $\mathrm{ET}_{\mathrm{a}}$ is estimated only at field scale or few miles $( \pm 20)$ from atmometer location, whereas with remote sensing $\mathrm{ET}_{\mathrm{a}}$ is estimated at field, local, and regional scales.

In conclusion the results of this study can be used by researchers and producers to estimate actual evapotranspiration and improve irrigation water management at regional and field scales using satellite-based remote sensing METRIC model method and at field scale using atmometer method.

\section{Disclosure}

This article is a part of a doctoral thesis: http://openprairie .sdstate.edu/cgi/viewcontent.cgi? article $=2785 \&$ context $=$ etd.

\section{Conflicts of Interest}

The authors declare no conflicts of interest.

\section{Authors' Contributions}

Arturo Reyes-González, Todd Trooien, and Jeppe Kjaersgaard conceived and designed the research. Arturo ReyesGonzález and Jeppe Kjaersgaard analyzed satellite images and $\mathrm{ET}_{\mathrm{a}}$ graphs. Arturo Reyes-González, Todd Trooien, and Jeppe Kjaersgaard contributed to the data analysis and discussion of the results. Laurent Ahiablame and Christopher Hay provided a critical revision of the manuscript. All authors contributed to reviewing the final paper.

\section{Acknowledgments}

The first author would like to acknowledge the National Council for Science and Technology of México (CONACYT) and the National Institute of Forestry, Agriculture, and Livestock Research (INIFAP) for funding his doctoral scholarship. Additional funding is provided by the South Dakota Agricultural Experiment Station, South Dakota Water Resources Institute, and South Dakota Corn Utilization Council. The authors would like to thank Ryan Vanderleest and Nathan Edwards for providing meteorological datasets.

\section{References}

[1] R. Allen, A. Irmak, R. Trezza, J. M. H. Hendrickx, W. Bastiaanssen, and J. Kjaersgaard, "Satellite-based ET estimation in agriculture using SEBAL and METRIC," Hydrological Processes, vol. 25, no. 26, pp. 4011-4027, 2011.

[2] M. C. Anderson, R. G. Allen, A. Morse, and W. P. Kustas, "Use of Landsat thermal imagery in monitoring evapotranspiration and managing water resources," Remote Sensing of Environment, vol. 122, pp. 50-65, 2012.

[3] M. E. Jensen and R. G. Allen, "Evaporation, evapotranspiration, and irrigation water requirements," in ASCE Manuals and Reports on Engineering Practice, vol. 70, p. 744, 2nd edition, 2016.

[4] P. S. Thenkabail, M. A. Hanjra, V. Dheeravath, and M. Gumma, "A holistic view of global croplands and their water use for ensuring global food security in the 21st century through advanced remote sensing and non-remote sensing approaches," Remote Sensing, vol. 2, no. 1, pp. 211-261, 2010.

[5] M. G. Bos, R. A. L. Kselik, R. G. Allen, and D. J. Molden, Water Requirements for Irrigation and the Environment, Springer Science and Business Media, Dordrecht, Netherlands, 2009.

[6] R. G. Allen, M. Tasumi, A. Morse et al., "Satellite-based energy balance for mapping evapotranspiration with internalized calibration (METRIC) - applications," Journal of Irrigation and Drainage Engineering, vol. 133, no. 4, pp. 395-406, 2007.

[7] P. H. Gowda, J. L. Chavez, P. D. Colaizzi, S. R. Evett, T. A. Howell, and J. A. Tolk, "ET mapping for agricultural water management: present status and challenges," Irrigation Science, vol. 26, no. 3, pp. 223-237, 2008.

[8] R. G. Allen, L. S. Pereira, D. Raes, and M. Smith, "Crop evapotranspiration: guide-lines for computing crop requirements," in Irrigation and Drainage Paper, vol. 56, FAO, Rome, Italy, 1998.

[9] B. A. George, B. R. S. Reddy, N. S. Raghuwanshi, and W. W. Wallender, "Decision support system for estimating reference evapotranspiration," Journal of Irrigation and Drainage Engineering, vol. 128, no. 1, pp. 1-10, 2002.

[10] R. Allen, M. Tasumi, and R. Trezza, "Satellite-based energy balance for mapping evapotranspiration with internalized calibration (METRIC) - model," Journal of Irrigation and Drainage Engineering, vol. 133, no. 4, pp. 380-394, 2007.

[11] J. Kjaersgaard, R. Allen, and A. Irmak, "Improved methods for estimating monthly and growing season ET using METRIC applied to moderate resolution satellite imagery," Hydrological Processes, vol. 25, no. 26, pp. 4028-4036, 2011.

[12] J. Kjaersgaard, R. G. Allen, C. Robinson et al., "Computation of evapotranspiration in parts of South Platte and North Platte River basin using Landsat Imagery," in Proceedings of the Pecora 17-The Future of Land Imaging...Going Operational, Denver, Colo, USA, November 2008.

[13] J. L. Chávez, P. H. Gowda, S. R. Evett, P. D. Colaizzi, T. A. Howell, and T. Marek, "An application METRIC for ET mapping in the Texas high plains," in Proceedings of the ASABE Annual International Meeting, Minneapolis, Minn, USA, June 2007.

[14] R. K. Singh and A. Irmak, "Treatment of anchor pixels in the METRIC model for improved estimation of sensible and latent heat fluxes," Hydrological Sciences Journal, vol. 56, no. 5, pp. 895906, 2011.

[15] N. C. Healey, A. Irmak, T. J. Arkebauer et al., "Remote sensing and in situ-based estimates of evapotranspiration for subirrigated meadow, dry valley, and upland dune ecosystems in the semi-arid sand hills of Nebraska, USA," Irrigation and Drainage Systems, vol. 25, no. 3, pp. 151-178, 2011.

[16] B. Hankerson, J. Kjaersgaard, and C. Hay, "Estimation of evapotranspiration from fields with and without cover crops using remote sensing and in situ methods," Remote Sensing, vol. 4, no. 12, pp. 3796-3812, 2012.

[17] M. Carrasco-Benavides, S. Ortega-Farías, L. O. Lagos, J. Kleissl, L. Morales-Salinas, and A. Kilic, "Parameterization of the satellite-based model (METRIC) for the estimation of instantaneous surface energy balance components over a drip-irrigated vineyard," Remote Sensing, vol. 6, no. 11, pp. 11342-11371, 2014.

[18] M. T. Folhes, C. D. Rennó, and J. V. Soares, "Remote sensing for irrigation water management in the semi-arid Northeast of Brazil," Agricultural Water Management, vol. 96, no. 10, pp. 1398-1408, 2009.

[19] V. M. Gordillo, H. M. Flores, L. Tijerina, and R. Arteaga, "Estimation of evapotranspiration using energy balance and 
satellite images," Revista Mexicana de Ciencias Agrícolas, vol. 5, no. 1, pp. 143-155, 2014 (Spanish).

[20] H. Zhang, R. G. Anderson, and D. Wang, "Satellite-based crop coefficient and regional water use estimates for Hawaiian sugarcane," Field Crops Research, vol. 180, pp. 143-154, 2015.

[21] R. Liebert, J. Huntington, C. Morton, S. Sueki, and K. Acharya, "Reduced evapotranspiration from leaf beetle induced tamarisk defoliation in the Lower Virgin River using satellite-based energy balance," Ecohydrology, vol. 9, no. 1, pp. 179-193, 2016.

[22] M. Mkhwanazi, J. L. Chávez, and E. H. Rambikur, "Comparison of Large Aperture Scintillometer and satellite-based energy balance models in sensible heat flux and crop evapotranspiration determination," International Journal of Remote Sensing Applications, vol. 2, no. 1, pp. 24-30, 2012.

[23] R. Trezza, R. G. Allen, and M. Tasumi, "Estimation of actual evapotranspiration along the Middle Rio Grande of New Mexico using MODIS and landsat imagery with the METRIC model," Remote Sensing, vol. 5, no. 10, pp. 5397-5423, 2013.

[24] C. Santos, I. J. Lorite, M. Tasumi, R. G. Allen, and E. Fereres, "Integrating satellite-based evapotranspiration with simulation models for irrigation management at the scheme level," Irrigation Science, vol. 26, no. 3, pp. 277-288, 2008.

[25] M. Choi, W. P. Kustas, M. C. Anderson, R. G. Allen, F. Li, and J. H. Kjaersgaard, "An intercomparison of three remote sensing-based surface energy balance algorithms over a corn and soybean production region (Iowa, U.S.) during SMACEX," Agricultural and Forest Meteorology, vol. 149, no. 12, pp. 20822097, 2009.

[26] M. Choi, T. W. Kim, M. Park, and S. J. Kim, "Evapotranspiration estimation using the Landsat-5 Thematic Mapper image over the Gyungan watershed in Korea," International Journal of Remote Sensing, vol. 32, no. 15, pp. 4327-4341, 2011.

[27] M. P. Gonzalez-Dugo, C. M. U. Neale, L. Mateos et al., "A comparison of operational remote sensing-based models for estimating crop evapotranspiration," Agricultural and Forest Meteorology, vol. 149, no. 11, pp. 1843-1853, 2009.

[28] A. N. French, D. J. Hunsaker, and K. R. Thorp, "Remote sensing of evapotranspiration over cotton using the TSEB and METRIC energy balance models," Remote Sensing of Environment, vol. 158, pp. 281-294, 2015.

[29] T. A. Paço, I. Pôças, M. Cunha et al., "Evapotranspiration and crop coefficients for a super intensive olive orchard. An application of SIMDualKc and METRIC models using ground and satellite observations," Journal of Hydrology, vol. 519, pp. 2067-2080, 2014.

[30] N. Bhattarai, L. J. Quackenbush, M. Dougherty, and L. J. Marzen, "A simple Landsat-MODIS fusion approach for monitoring seasonal evapotranspiration at $30 \mathrm{~m}$ spatial resolution," International Journal of Remote Sensing, vol. 36, no. 1, pp. 115143, 2015.

[31] I. Broner and R. A. P. Law, "Evaluation of a modified atmometer for estimating reference ET," Irrigation Science, vol. 12, no. 1, pp. 21-26, 1991.

[32] M. Alam and T. P. Trooien, "Estimating reference evapotranspiration with an atmometer," Applied Engineering in Agriculture, vol. 17, no. 2, pp. 153-158, 2001.

[33] V. Magliulo, R. D’Andria, and G. Rana, "Use of the modified atmometer to estimate reference evapotranspiration in Mediterranean environments," Agricultural Water Management, vol. 63, no. 1, pp. 1-14, 2003.
[34] S. Irmak, M. D. Dukes, and J. M. Jacobs, "Using modified Bellani plate evapotranspiration gauges to estimate short canopy reference evapotranspiration," Journal of Irrigation and Drainage Engineering, vol. 131, no. 2, pp. 164-175, 2005.

[35] J. C. Mendonça, E. F. Sousa, S. Bernardo, G. P. Dias, and S. Grippa, "Comparação entre métodos de estimativa da evapotranspiração de referência (ETo) na região Norte Fluminense, RJ," Revista Brasileira de Engenharia Agrícola e Ambiental, vol. 7, no. 2, pp. 275-279, 2003 (Portuguese).

[36] M. P. Casanova, I. Messing, A. Joel, and A. M. Cañete, "Methods to estimate lettuce evapotranspiration in greenhouse conditions in the central zone of Chile," Chilean Journal of Agricultural Research, vol. 69, pp. 60-70, 2009.

[37] W. L. Pelton, "Evaporation from atmometers and pans," Canadian Journal of Plant Science, vol. 44, no. 5, pp. 397-404, 1964.

[38] G. J. Kidron, "Measurements of evaporation with a novel mini atmometer in the Negev," Weather, vol. 60, no. 9, pp. 268-272, 2005.

[39] J. W. Knox, J. A. Rodriguez-Diaz, and T. M. Hess, "Estimating evapotranspiration by using atmometers for irrigation scheduling in a humid environment," Journal of Irrigation and Drainage Engineering, vol. 137, no. 11, pp. 685-691, 2011.

[40] S. Taghvaeian, J. L. Chávez, W. C. Bausch, K. C. DeJonge, and T. J. Trout, "Minimizing instrumentation requirement for estimating crop water stress index and transpiration of maize," Irrigation Science, vol. 32, no. 1, pp. 53-65, 2014.

[41] D. Lamine, B. Ansoumana, and D. Dior, "Use of atmometers to estimate reference evapotranspiration in Arkansas," African Journal of Agricultural Research, vol. 10, no. 48, pp. 4376-4383, 2015.

[42] K. W. Peterson, D. J. Bremer, and J. D. Fry, "Evaluation of atmometers within urban home lawn microclimates," Crop Science, vol. 55, no. 5, pp. 2359-2367, 2015.

[43] A. Reyes-González, T. Trooien, C. Hay, and J. Kjaersgaard, "Comparison of reference evapotranspiration estimates by automated weather station and measured an atmometer," in Proceedings of the 2016 Western South Dakota Hydrology Conference, Rapid City, SD, USA, April 2016.

[44] Soil Survey Staff, Natural Resources Conservation Service, Unite States Department of Agriculture. Web soil survey, October 2016, http://websoilsurvey.nrcs.usda.gov.

[45] B. D. Keim, "The lasting scientific impact of the thornthwaite water-balance model," Geographical Review, vol. 100, no. 3, pp. 295-300, 2010.

[46] USGS-GLOVIS, “Global visual viewer,” 2011, http://glovis.usgs .gov.

[47] J. Kjaersgaard and R. G. Allen, "Remote sensing technology to produce consumptive water use maps for the Nebraska Panhandle," Tech. Rep. 88, University of Nebraska, Lincoln, Neb, USA, 2010.

[48] USGS-Landsat, 2016, http://landsat.usgs.gov/gap-filling-landsat7-slc-single-scenes-using-erdas-imagine-TM.

[49] W. G. M. Bastiaanssen, E. J. M. Noordman, H. Pelgrum, G. Davids, B. P. Thoreson, and R. G. Allen, "SEBAL model with remotely sensed data to improve water-resources management under actual field conditions," Journal of Irrigation and Drainage Engineering, vol. 131, no. 1, pp. 85-93, 2005.

[50] M. Tasumi, R. G. Allen, R. Trezza, and J. L. Wright, "Satellitebased energy balance to assess within-population variance of crop coefficient curves," Journal of Irrigation and Drainage Engineering, vol. 131, no. 1, pp. 94-109, 2005. 
[51] M. Tasumi, Progress in operational estimation of regional evapotranspiration using satellite imagery [Ph.D. thesis], University of Idaho, Moscow, Idaho, USA, 2003.

[52] W. G. M. Bastiaanssen, M. Menenti, R. A. Feddes, and A. A. M. Holtslag, "A remote sensing surface energy balance algorithm for land (SEBAL): 1. Formulation," Journal of Hydrology, vol. 212, no. 1-4, pp. 198-212, 1998.

[53] J. L. Wright, "New evapotranspiration crop coefficients," Journal of the Irrigation \& Drainage Division, vol. 108, pp. 57-74, 1982.

[54] ASCE-EWRI, "The ASCE Standardized Reference Evapotranspiration Equation," Report of the ASCE-EWRI Task Committee on Standardization of Reference Evapotranspiration, ASCE, Reston, Va, USA, 2005.

[55] P. Gavilán and F. Castillo-Llanque, "Estimating reference evapotranspiration with atmometers in a semiarid environment," Agricultural Water Management, vol. 96, no. 3, pp. 465-472, 2009.

[56] S. Irmak, L. O. Odhiambo, J. E. Specht, and K. Djaman, "Hourly and daily single and basal evapotranspiration crop coefficients as a function of growing degree days, days after emergence, leaf area index, fractional green canopy cover, and plant phenology for soybean," Transactions of the ASABE, vol. 56, no. 5, pp. 17851803, 2013.

[57] C. J. Willmott, "On the validation of models," Physical Geography, vol. 2, no. 2, pp. 184-194, 1981.

[58] K. Djaman and S. Irmak, "Actual crop evapotranspiration and alfalfa- and grass-reference crop coefficients of maize under full and limited irrigation and rainfed conditions," Journal of Irrigation and Drainage Engineering, vol. 139, no. 6, pp. 433-446, 2013.

[59] A. Reyes-González, T. Trooien, J. Kjaersgaard, C. Hay, and D. G. Reta-Sánchez, "Development of crop coefficients using remote sensing-based vegetation index and growing degree days," in Proceedings of the ASABE Annual International Meeting, Orlando, Fla, USA, July 2016.

[60] A. Irmak and S. Irmak, "Reference and crop evapotranspiration in South Central Nebraska. II: Measurement and estimation of actual evapotranspiration for corn," Journal of Irrigation and Drainage Engineering, vol. 134, no. 6, pp. 700-715, 2008.

[61] R. K. Singh and A. Irmak, "Estimation of crop coefficients using satellite remote sensing," Journal of Irrigation and Drainage Engineering, vol. 135, no. 5, pp. 597-608, 2009.

[62] P. Droogers, W. W. Immerzeel, and I. J. Lorite, "Estimating actual irrigation application by remotely sensed evapotranspiration observations," Agricultural Water Management, vol. 97, no. 9, pp. 1351-1359, 2010.

[63] G. Carrillo-Rojas, B. Silva, M. Córdova, R. Célleri, and J. Bendix, "Dynamic mapping of evapotranspiration using an energy balance-based model over an andean páramo catchment of southern ecuador," Remote Sensing, vol. 8, no. 2, article 160, 2016.

[64] C. G. Morton, J. L. Huntington, G. M. Pohll, R. G. Allen, K. C. Mcgwire, and S. D. Bassett, "Assessing calibration uncertainty and automation for estimating evapotranspiration from agricultural areas using METRIC," JAWRA Journal of the American Water Resources Association, vol. 49, no. 3, pp. 549-562, 2013.

[65] D. J. Gleason, A. A. Andales, T. A. Bauder, and J. L. Chávez, "Performance of atmometers in estimating reference evapotranspiration in a semi-arid environment," Agricultural Water Management, vol. 130, pp. 27-35, 2013.
[66] F. Chen and P. J. Robinson, "Estimating reference crop evapotranspiration with ETgages," Journal of Irrigation and Drainage Engineering, vol. 135, no. 3, pp. 335-342, 2009.

[67] R. G. Anderson, D. Wang, R. Tirado-Corbalá, H. Zhang, and J. E. Ayars, "Divergence of actual and reference evapotranspiration observations for irrigated sugarcane with windy tropical conditions," Hydrology and Earth System Sciences, vol. 19, no. 1, pp. 583-599, 2015.

[68] R. S. Westerhoff, "Using uncertainty of Penman and PenmanMonteith methods in combined satellite and ground-based evapotranspiration estimates," Remote Sensing of Environment, vol. 169, pp. 102-112, 2015.

[69] M. H. Mokhtari, B. Ahmad, H. Hoveidi, and I. Busu, "Sensitivity analysis of METRIC-based evapotranspiration algorithm," International Journal of Environmental Research, vol. 7, no. 2, pp. 407-422, 2013. 


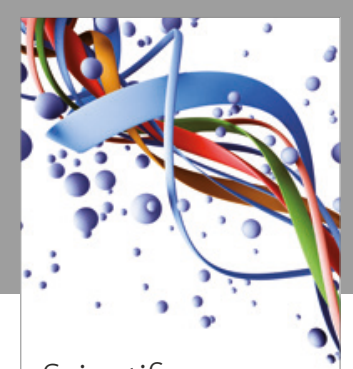

Scientifica
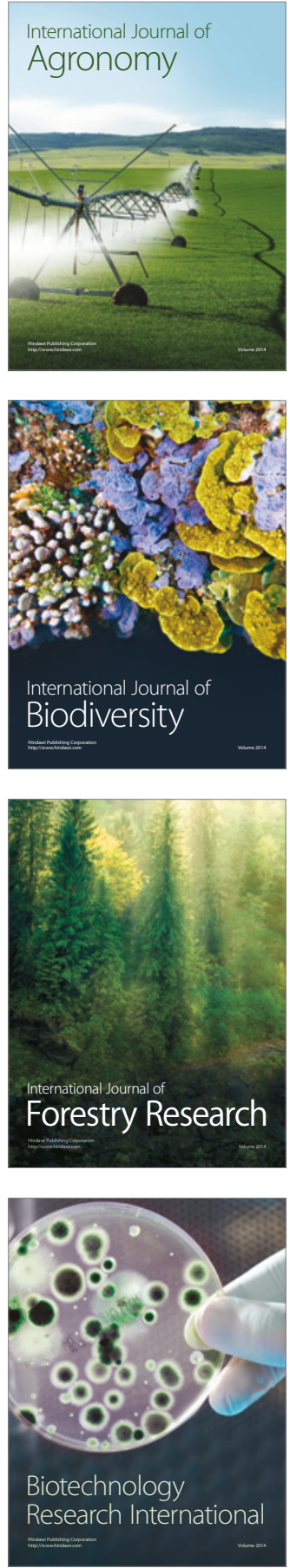
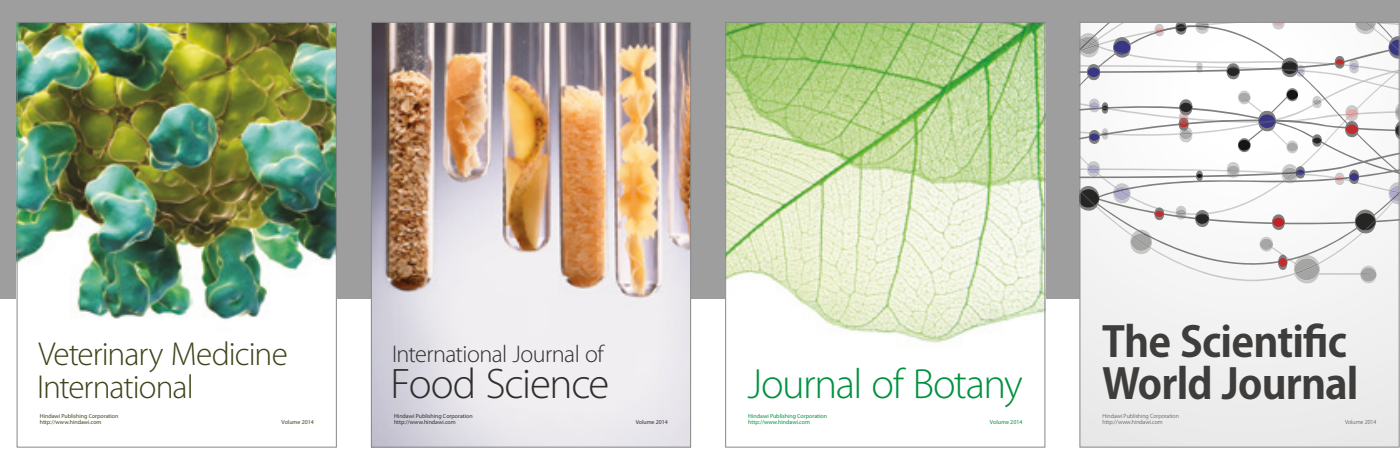

The Scientific

\section{World Journal}

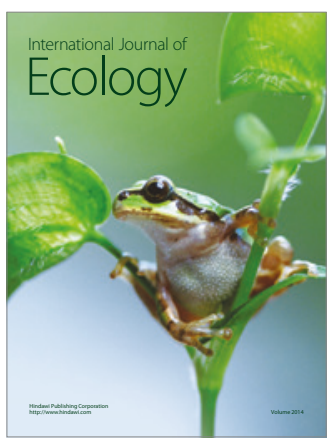

\section{Hindawi}

Submit your manuscripts at

https://www.hindawi.com
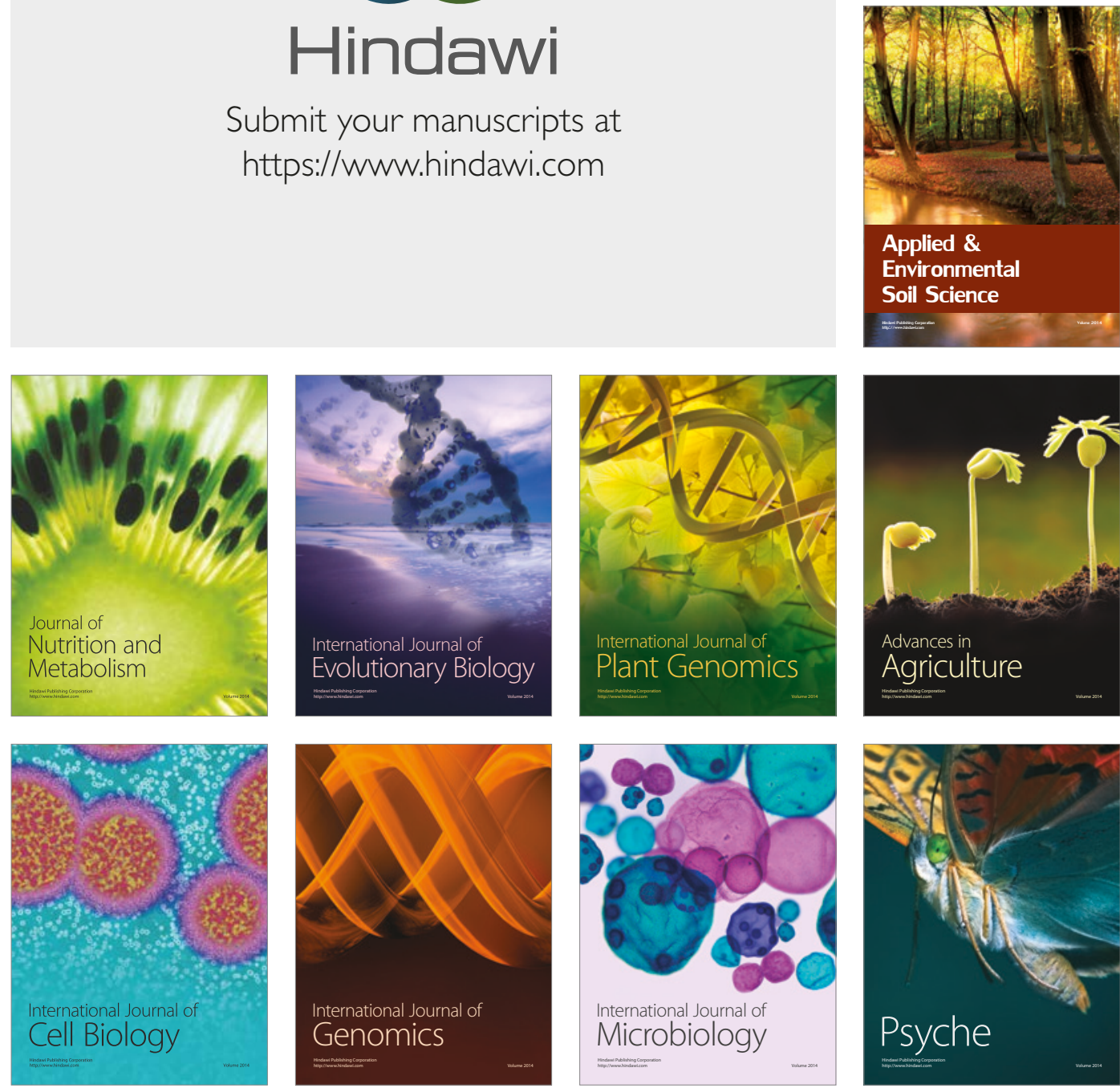

hternational Journal of Microbiology
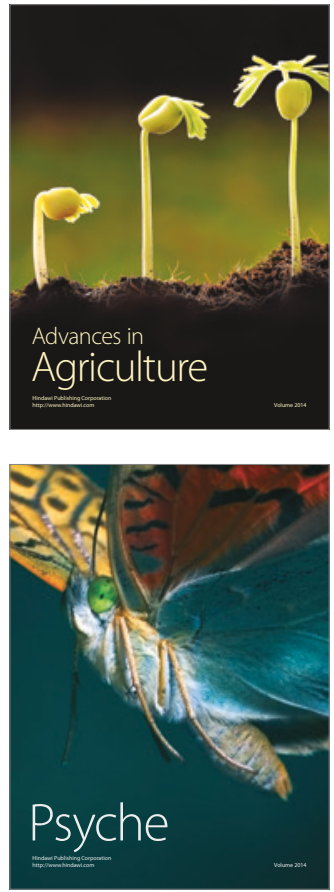